\title{
Chemical Constituents of Aristolochia giberti
}

\author{
Alessandra M. Marchesini, Giovana G. Prado, Gisele B. Messiano, \\ Marcos B. Machado and Lucia M. X. Lopes*
}

Instituto de Química, Universidade Estadual Paulista, CP 355, 14801-970 Araraquara-SP, Brazil

\begin{abstract}
Foram isoladas quatorze substâncias de Aristolochia giberti, entre elas, um novo triterpeno, (-)-onocera-8,8'-diol. Além destas, 3-hidróxipropanoato, acetato e formato foram detectados por técnicas de RMN, o que sugere que estas substâncias sejam derivadas do 2-butinodioato, não detectável por RMN de ${ }^{1} \mathrm{H}$. As análises dos óleos essenciais de caules e folhas, por CG-EM e quimiometria, mostraram grande similaridade entre as espécies cultivadas no Brasil e aquelas na Argentina, o que permitiu confirmar a identificação da espécie e diferenciar os óleos de acordo com as partes da planta.
\end{abstract}

Fourteen compounds were isolated from Aristolochia giberti. These included a new triterperne, (-)-onocera-8,8'-diol. In addition, 3-hydroxypropanoate, acetate, and formate were detected by NMR techniques, which suggests that they are derivatives from 2-butynedioate, which is not detected by ${ }^{1} \mathrm{H}$ NMR. GC-MS and chemometric analyses of essential oils from stems and leaves showed great similarity between this cultivated species in Brazil and that in Argentina, which allowed us to confirm the species identity and to differentiate the oils according to the plant parts.

Keywords: Aristolochia giberti, Aristolochiaceae, (-)-onocera-8,8'-diol, essential oil, 2-butynedioate

\section{Introduction}

Aristolochia species (Aristolochiaceae) are generally sold at Brazilian markets under their popular names, particularly as "One Thousand Man", and little distinction has been made among the species. They have been mainly used in Brazilian traditional medicine as abortifacients, stomachics, antiophidians, antiasthmatics, and expectorants, and recently in slimming therapies. ${ }^{1,2}$ Aristolochic acids constitute a class of compounds that are characteristic of the Aristolochia genus. These acids have been associated with Chinese herb nephropathy, which is a kind of severe kidney disease caused by the intake of excessive aristolochic acids. ${ }^{3}$ Therefore, it is essential, for health safety and quality control of related Brazilian herbal medicines, to know the chemical composition of these species, among them Aristolochia giberti Hook., and to develop efficient methods for species identification.

The chemical constituents of Brazilian Aristolochiaceae species, such as lignans, have shown antiplasmodial, ${ }^{4}$ antimycobacterial, ${ }^{5}$ insecticidal, ${ }^{6,7}$ anti-inflammatory, and analgesic activities. ${ }^{8}$

*e-mail: lopesxl@iq.unesp.br
Despite the significant number of Brazilian Aristolochia species (around 100), the volatile compounds they contain are known for only a few species. ${ }^{9}$ In our previous studies on essential oils from roots of 10 Aristolochia species, we investigated the oil composition and correlated them to morphological groups by GC-MS and chemometric analyses, which could also help in the identification of these species. ${ }^{9}$

A total of 64 compounds were identified in the analysed essential oils from stems and leaves of $A$. giberti collected in Argentina and Paraguay, which corresponded to around $77 \%$ to $92 \%$ of the constituents in the oils. ${ }^{10,11}$ Methanolic extracts of $A$. giberti protected against enzymatic and non-enzymatic lipid peroxidation in microsomal membranes of rat. ${ }^{12}$

The goals of the present study were to investigate the chemical composition of the leaf and stem extracts and the nature of the essential oils from stems and leaves of cultivated A. giberti in Brazil, to correlate its oil composition to those reported in the literature for plants collected in Argentina ${ }^{10}$ and Paraguay, ${ }^{11}$ and then to obtain information about interspecific variability as a function of provenance by using GC-MS and chemometric analyses as tools for plant identification. 


\section{Experimental}

\section{Instrumentation}

One-dimensional $\left({ }^{1} \mathrm{H},{ }^{13} \mathrm{C}\right.$, DEPT, and gNOESY $)$ and two-dimensional $\left({ }^{1} \mathrm{H}-{ }^{1} \mathrm{H} g \mathrm{COSY}, g \mathrm{HMQC}, g \mathrm{HMBC}\right.$, and gNOESY) NMR experiments were recorded on a Varian INOVA 500 spectrometer $(11.7 \mathrm{~T})$ at $500 \mathrm{MHz}\left({ }^{1} \mathrm{H}\right)$ and $126 \mathrm{MHz}\left({ }^{13} \mathrm{C}\right)$, using the residual solvents as an internal standard. Mass spectra (electrospray ionization-mass spectroscopy (ESI-MS)) were performed on a Fisons Platform II, and flow injection into the electrospray source was used for ESI-MS. Infrared spectra (IR) were obtained on a Perkin Elmer 1600 FT-IR spectrometer using $\mathrm{KBr}$ disks. Ultraviolet (UV) absorptions were measured on a Perkin Elmer UV-Vis Lambda 14P diode array spectrophotometer. Optical rotations were measured on a Perkin Elmer 341-LC polarimeter. Melting points were recorded on a Microquímica MQAPF-301 melting point apparatus and were uncorrected. GC-MS analyses were performed on a Shimadzu GCMS-QP5050A system in EI mode $(70 \mathrm{eV})$ equipped with a split/splitless injector $\left(220^{\circ} \mathrm{C}\right)$, at a split ratio of $1 / 10$, using a VF-1MS fused-silica capillary column (30 $\mathrm{m}$ by $0.25 \mathrm{~mm}$ i.d.; film thickness: $0.25 \mu \mathrm{m})$. The oven temperature was programmed from $60{ }^{\circ} \mathrm{C}(5 \mathrm{~min})$ to $280{ }^{\circ} \mathrm{C}$ at a rate of $4{ }^{\circ} \mathrm{C} \mathrm{min}^{-1}$ and held at this temperature for $10 \mathrm{~min}$. Helium was used as a carrier gas at a flow rate of $0.8 \mathrm{~mL} \mathrm{~min}{ }^{-1}$. The injection volume of each sample was $2 \mu \mathrm{L}$.

\section{Solvents}

Nanopure water (>18.2 $\mathrm{M} \Omega \mathrm{cm})$ was obtained using a Millipore purifier (Bedford, MA) and filtered through a Millipore membrane. All of the HPLC- and GC-grade solvents were purchased from Mallinckrodt Baker Inc. (Paris, KY); all organic solvents were filtered through Millipore PTFE membranes $(0.5 \mu \mathrm{m}, 47.0 \mathrm{~mm})$ prior to use, and samples were filtered through Millipore polyvinylidene fluoride (PVDF) membranes $(0.45 \mu \mathrm{m}, 13.0 \mathrm{~mm}) . \mathrm{CDCl}_{3}$, DMSO- $d_{6}$, and $\mathrm{D}_{2} \mathrm{O}(\geq 99.98 \% \mathrm{D})$ for NMR analyses were purchased from Cambridge Isotope Laboratories, Inc. (CIL, Andover, MA).

\section{Adsorbents}

Silica gel $60 \mathrm{PF}_{254}$ for thin-layer chromatography (PTLC) was purchased from Aldrich (Milwaukee, WI), and silica gel $60 \mathrm{H}$ and silica gel 70-325 mesh for column chromatography (CC) were obtained from Merck (Darmstadt, Germany).

\section{Plant material}

The plant material was collected in Araraquara, SP, Brazil, in February, 2003, and identified as Aristolochia giberti Hook. (Aristolochiaceae) by Dr. Condorcet Aranha and Dr. Lindolpho Capellari Júnior (Escola Superior de Agricultura "Luiz de Queiroz" (ESALQ), Piracicaba, SP, Brazil). A voucher specimen (ESA 88888) was deposited at the herbarium of the ESALQ, Piracicaba, SP, Brazil. The material was separated according to the plant parts, dried (ca. $45^{\circ} \mathrm{C}$ ), and ground.

\section{Extraction and isolation of the chemical constituents}

The leaves (306.2 g) and stems (1116.5 g) were extracted exhaustively at room temperature with hexane, acetone, and ethanol, successively. The residues were extracted with ethanol in a Soxhlet apparatus and the extracts were individually concentrated.

The stem crude hexane extract $(10.0 \mathrm{~g})$ was subjected to CC (5.0 by $35.0 \mathrm{~cm}$; silica gel 70-325 mesh; $270.0 \mathrm{~g}$; hexane/EtOAc gradient, 95:5 to $100 \%$ EtOAc) to give 16 fractions ( $c a .200 \mathrm{~mL}$ each). Fractions 7, 8, and 11 gave 6 (858.5 mg), $\mathbf{1 0}(602.0 \mathrm{mg})$, and $\mathbf{8}(618.3 \mathrm{mg})$, respectively. Fractions 15 and 16 gave 2 (654.1 mg). Fractions 9 and 14 were individually subjected to PTLC (hexane/EtOAc, 4:1) to give 7 (48.4 mg) and 3 (10.7 mg), respectively (Figure 1).

The crude ethanol extract from leaves $(9.09 \mathrm{~g})$ was also subjected to CC (5.0 by $28.0 \mathrm{~cm}$; silica gel $60 \mathrm{H}$; $220.0 \mathrm{~g}$; $\mathrm{CHCl}_{3} / \mathrm{MeOH}$ gradient, 95:5 to $100 \% \mathrm{MeOH}$ ) to give 25 fractions ( $c a .150 \mathrm{~mL}$ each). Fractions 15, 20, and 25 gave $4(87.0 \mathrm{mg}), \mathbf{5}(44.0 \mathrm{mg})$, and $\mathbf{2}(731.2 \mathrm{mg})$, respectively. Fraction 7 by PTLC ( $\left.\mathrm{CHCl}_{3} / \mathrm{EtOAc}, 9: 1\right)$ gave 8 (40.8 mg), and fraction 9 by PTLC $\left(\mathrm{CHCl}_{3} / \mathrm{EtOAc}, 7: 3\right)$ gave $\mathbf{1}(24.3$ $\mathrm{mg}), \mathbf{8}(31.5 \mathrm{mg}$ ), and 9 (60.9 $\mathrm{mg}$ ) (Figure 1).

The crude ethanol Soxhlet extract from the leaves $(14.3 \mathrm{~g})$ was washed with $\mathrm{CHCl}_{3}$ to give two fractions: a soluble $(3.8 \mathrm{~g})$ and an insoluble $(10.5 \mathrm{~g})$ in $\mathrm{CHCl}_{3}$. A portion of the soluble fraction $(1.1 \mathrm{~g})$ was subjected to flash CC (4.0 by $5.0 \mathrm{~cm}$; silica gel $60 \mathrm{H} ; 24.0 \mathrm{~g}$; hexane/ EtOAc gradient $90: 10$ to $100 \%$ EtOAc, and then $100 \%$ $\mathrm{MeOH}$ ) to give 18 fractions (ca. $100 \mathrm{~mL}$ each). Fraction 5 gave $4(115.2 \mathrm{mg})$ and fraction 16 gave $2(919.8 \mathrm{mg})$. Fraction 10, after PTLC (hexane/EtOAc, 7:3), gave 7 (1.0 mg). The insoluble $\mathrm{CHCl}_{3}$ fraction $(7.9 \mathrm{~g})$ was partially dissolved in $\mathrm{MeOH}$ to give a $\mathrm{MeOH}$ subfraction $(1.6 \mathrm{~g})$ and a precipitate $(4.4 \mathrm{~g})$. The $\mathrm{MeOH}$ subfraction was subjected to CC [5.0 by $28.0 \mathrm{~cm}$; silica gel $60 \mathrm{H}$; $220.6 \mathrm{~g} ; \mathrm{CHCl}_{3} /(\mathrm{MeOH}+0.5 \% \mathrm{HOAc})$ gradient, 95:5 to $100 \%(\mathrm{MeOH}+0.5 \% \mathrm{HOAc})]$ to give 15 fractions (ca. $100 \mathrm{~mL}$ each). Fractions 3, 4, 7, and 13 gave 2 

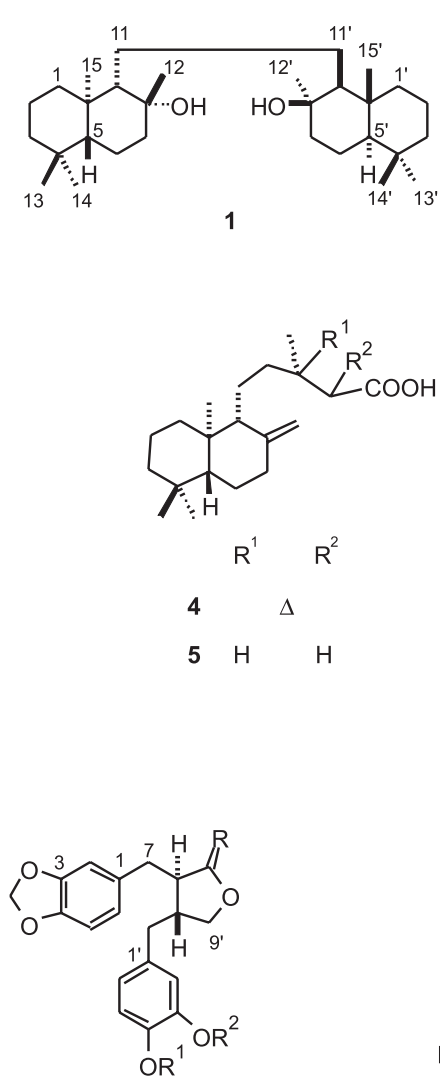

\begin{tabular}{lllll} 
& $\mathrm{R}$ & $\mathrm{R}^{1}$ & \multicolumn{2}{c}{$\mathrm{R}^{2}$} \\
7 & $\mathrm{O}$ & \multicolumn{2}{c}{$\mathrm{CH}_{2}$} \\
8 & $\mathrm{O}$ & $\mathrm{CH}_{3} \quad \mathrm{CH}_{3}$ \\
9 & $\mathrm{H}, \mathrm{OH}$ & $\mathrm{CH}_{2}$
\end{tabular}

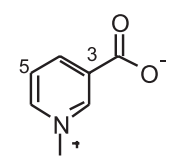

12

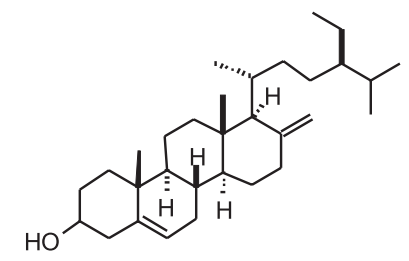

10

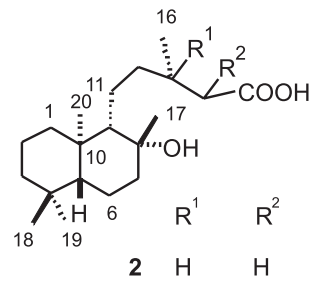

$3 \Delta$

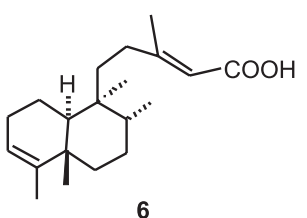<smiles>CO[C@H]1C(O)[C@H](O)[C@@H](O)[C@H](O)[C@H]1O</smiles>

11<smiles>O=c1cc[nH]c(=O)[nH]1</smiles>

13

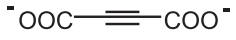

14

Figure 1. Chemical structures for compounds 1-14.

(14.1 mg), $\mathbf{1 3}(4.0 \mathrm{mg}), \mathbf{1 1}(266.2 \mathrm{mg})$, and $\mathbf{1 2}(42.2 \mathrm{mg})$, respectively. Fraction 12 gave $\mathbf{1 4}$ as an amorphous solid $(34.3 \mathrm{mg})$ which, after repetitive precipitation procedures from $\mathrm{MeOH} / \mathrm{H}_{2} \mathrm{O}$, gave a mixture of $\mathbf{1 5}, \mathbf{1 6}$, and $\mathbf{1 7}$ in the soluble solutions that were reunited (Figure 1).

Mixture of 3-Hydroxypropanoate (15) + Acetate (16) + Formate (17) was analysed in $\mathrm{D}_{2} \mathrm{O}$ and DMSO- $d_{6}$ solutions by ${ }^{1} \mathrm{H}$ and ${ }^{13} \mathrm{C}$ NMR.

\section{3-Hydroxypropionate (15)}

${ }^{1} \mathrm{H}$ NMR ( $\left.\mathrm{D}_{2} \mathrm{O}\right) \delta 3.77(\mathrm{t}, J 6.5 \mathrm{~Hz}, 2 \mathrm{H}-3), 2.40(\mathrm{t}, J$ $6.5 \mathrm{~Hz}, 2 \mathrm{H}-2) ;{ }^{13} \mathrm{C}$ NMR $\left(\mathrm{D}_{2} \mathrm{O}\right) \delta 180.6$ (C-1), $40.0(\mathrm{C}-2)$, 59.1 (C-3).
Acetate (16)

${ }^{1} \mathrm{H}$ NMR $\left(\mathrm{D}_{2} \mathrm{O}\right) \delta 1.89(\mathrm{~s}, 3 \mathrm{H}-2) ;{ }^{13} \mathrm{C}$ NMR $\left(\mathrm{D}_{2} \mathrm{O}\right) \delta$ 181.4 (C-1), 23.0 (C-2).

\section{Formate (17)}

${ }^{1} \mathrm{H}$ NMR $\left(\mathrm{D}_{2} \mathrm{O}\right) \delta 8.43(\mathrm{~s}, \mathrm{H}-1),{ }^{13} \mathrm{C} \mathrm{NMR}\left(\mathrm{D}_{2} \mathrm{O}\right) \delta 167.0$.

(-)-Onocera-8, 8'-diol (1)

Colorless oil; $[\alpha]_{\mathrm{D}}^{27}-4.0^{\circ}\left(\mathrm{c} 0.2, \mathrm{CHCl}_{3}\right)$; for ${ }^{1} \mathrm{H}$ NMR $\left(500 \mathrm{MHz}, \mathrm{CDCl}_{3}\right)$ and ${ }^{13} \mathrm{C} \mathrm{NMR}\left(126 \mathrm{MHz}, \mathrm{CDCl}_{3}\right)$ spectra see Table 1; ESI-HR-TOF-MS (probe) ESI-MS, $+50 \mathrm{~V}, \mathrm{~m} / z$ (rel. int.): $469.4018[\mathrm{M}+\mathrm{Na}]^{+}(100)$ (calculated for $\mathrm{C}_{30} \mathrm{H}_{54} \mathrm{O}_{2}+\mathrm{Na}=469.4016$ ). 
Table 1. NMR data for compound $\mathbf{1}^{\mathrm{a}}$

\begin{tabular}{|c|c|c|c|}
\hline Position & $\delta_{\mathrm{C}}^{\mathrm{b}}$ & $g \mathrm{HMBC}$ & $\delta_{\mathrm{H}}{ }^{\mathrm{c}}$ \\
\hline \multirow[t]{2}{*}{1,1} & $39.2 \mathrm{t}$ & $\mathrm{H}-15,15^{\prime}$ & $1.59 \mathrm{~m}$ \\
\hline & & & $0.78 \mathrm{~m}$ \\
\hline \multirow[t]{2}{*}{2,2} & $18.4 \mathrm{t}$ & $\mathrm{H}-1,1^{\prime}$ & $1.52 \mathrm{~m}$ \\
\hline & & & $1.20 \mathrm{~m}$ \\
\hline \multirow[t]{2}{*}{3,3} & $42.2 \mathrm{t}$ & H-13,13', H-14,14' & $1.33 \mathrm{~m}$ \\
\hline & & & $1.08 \mathrm{~m}$ \\
\hline $4,4^{\prime}$ & $33.5 \mathrm{~s}$ & H-5,5', H-13,13', H-14,14' & - \\
\hline 5,5 & $56.0 \mathrm{~d}$ & H-13,13', H-14,14', H-15,15' & $0.75 \mathrm{~m}$ \\
\hline \multirow[t]{2}{*}{6,6} & $18.3 \mathrm{t}$ & $\mathrm{H}-5,5$ & $1.52 \mathrm{~m}$ \\
\hline & & & $1.44 \mathrm{~m}$ \\
\hline \multirow[t]{2}{*}{7,7} & $42.3 \mathrm{t}$ & H-12,12' & $1.68 \mathrm{~m}$ \\
\hline & & & $1.34 \mathrm{~m}$ \\
\hline 8,8 & $73.3 \mathrm{~s}$ & $\mathrm{H}-12,12$ & - \\
\hline 9,9 ' & $59.5 \mathrm{~d}$ & $\begin{array}{l}\text { H-1,1', H-11,11', } \\
\text { H-12,12', H-15,15', }\end{array}$ & $0.66 \mathrm{~m}$ \\
\hline $10,10^{\prime}$ & $39.0 \mathrm{~s}$ & H-11,11', H-15,15' & - \\
\hline $11,11^{\prime}$ & $20.1 \mathrm{t}$ & & $0.89 \mathrm{~m}$ \\
\hline $12,12^{\prime}$ & $30.7 \mathrm{q}$ & & $1.05 \mathrm{~s}$ \\
\hline $13,13^{\prime}$ & $33.3 \mathrm{q}$ & & $0.80 \mathrm{~s}$ \\
\hline $14,14^{\prime}$ & $21.7 \mathrm{q}$ & H-13,13' & $0.76 \mathrm{~s}$ \\
\hline $15,15^{\prime}$ & $15.2 \mathrm{q}$ & & $0.88 \mathrm{~s}$ \\
\hline
\end{tabular}

${ }^{a}$ The ${ }^{1} \mathrm{H}$ and ${ }^{13} \mathrm{C}$ NMR data were assigned with the assistance of DEPT $90^{\circ}$ and $135^{\circ}, g \mathrm{HMQC}, g \mathrm{HMBC}$, and ${ }^{1} \mathrm{H}-{ }^{1} \mathrm{H}$ COSY experiments (11.7 $\mathrm{T})$; ${ }^{\circ}$ Recorded in $\mathrm{CDCl}_{3}, 126 \mathrm{MHz}$; 'Recorded in $\mathrm{CDCl}_{3}, 500 \mathrm{MHz}$.

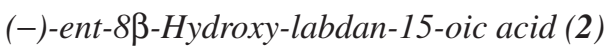

Colorless oil; $[\alpha]_{\mathrm{D}}^{25}-10.5^{\circ}\left(c 0.2, \mathrm{CHCl}_{3}\right) ;{ }^{1} \mathrm{H} \mathrm{NMR}$ $\left(500 \mathrm{MHz}, \mathrm{CDCl}_{3}\right) \delta 2.36(1 \mathrm{H}, \mathrm{dd}, J 15.0,6.0 \mathrm{~Hz}, \mathrm{H}-14)$, 2.16 (1H, ddq, J 15.0, 8.0, 1.0, Hz, H-14), 1.74 (1H, dd, $J$ 13.0, 3.0 Hz, H-7), 1.67 (1H, m, H-6), 1.64 (1H, br, d, $J$ 14.0, H-1), 1.57 (1H, m, H-11 or H-12), 1.50 (2H, m, H-2, H-6), 1.47 (1H, m, H-7), 1.37 (2H, m, H-3, H-12), 1.33 (1H, m, H-11), 1.24 (1H, m, H-11 or H-12), 1.13 (2H, m, H-3, H-13), 1.11 (3H, s, H-17), 0.98 (1H, m, H-2), 0.98 (3H, dd, J 6.5, $1.0 \mathrm{~Hz}, \mathrm{H}-16), 0.94$ (3H, s, H-20), 0.86 (3H, s, H-18), 0.84 (1H, m, H-1), 0.82 (3H, s, H-19), 0.81 (1H, m, H-5), 0.74 (1H, br, s, H-9); ${ }^{13} \mathrm{C}$ NMR (126 MHz, $\left.\mathrm{CDCl}_{3}\right) \delta 178.4$ (C-15), 73.5 (C-8), 59.3 (C-9), 55.9 (C-5), 42.1 (C-7), 42.0 (C-3), 41.3 (C14), 40.6 (C-12), 39.2 (C-1), 38.9 (C-10), 33.4 (C-18), 33.2 (C-4), 31.1 (C-13), 30.4 (C-17), 22.5 (C-11), 21.6 (C-19), 19.7 (C-16), 18.3 (C-2), 18.1 (C-6), 15.1 (C-20); ESI-MS, $m / z, 325[\mathrm{M}+\mathrm{H}]^{+}$.

\section{(-)-ent-8ß-Hydroxy-labd-13(E)-en-15-oic acid (3)}

Colorless oil; $[\alpha]_{\mathrm{D}}^{25}-10.0^{\circ}\left(c 0.1, \mathrm{CHCl}_{3}\right) ;{ }^{1} \mathrm{H} \mathrm{NMR}$ $\left(500 \mathrm{MHz} \mathrm{CDCl}_{3}\right) \delta 5.68(1 \mathrm{H}, \mathrm{br}, \mathrm{s}, \mathrm{H}-14), 2.28(1 \mathrm{H}, \mathrm{m}$,
H-12), 2.12 (3H, br, s, H-16), 2.10 (1H, m, H-12), 1.69 (1H, m, H-7), 1.60 (1H, m, H-1), 1.54 (2H, m, H-2, H-11), 1.50 (1H, m, H-6), 1.44 (2H, m, H-6, H-7), 1.37 (1H, m, H-11), 1.33 (1H, m, H-3), 1.08 (1H, m, H-3), 1.08 (3H, s, H-17), 0.90 (1H, m, H-2), 0.89 (3H, s, H-20), 0.81 (3H, s, H-18), 0.81 (1H, m, H-1), 0.78 (1H, m, H-5), 0.76 (3H, s, $\mathrm{H}-19), 0.74$ (1H, m, H-9); $\left.{ }^{13} \mathrm{C} \mathrm{NMR} \mathrm{(126} \mathrm{MHz,} \mathrm{CDCl}_{3}\right) \delta$ 170.0 (C-15), 163.0 (C-13), 114.8 (C-14), 72.9 (C-8), 58.4 (C-9), 55.8 (C-5), 44.5 (C-12), 42.2 (C-7), 41.8 (C-3), 39.0 (C-1), 33.0 (C-4, C-18), 30.3 (C-17), 21.5 (C-19), 19.6 (C2, C-11), 18.8 (C-16), 17.8 (C-6), 14.4 (C-20); ESI-MS, $m / z 323[\mathrm{M}+\mathrm{H}]^{+}$.

\section{(-)-Copalic acid (4)}

Colorless oil; $[\alpha]_{\mathrm{D}}^{25}-34.2^{\circ}\left(c 0.5, \mathrm{CHCl}_{3}\right)$ [lit. $-33.7^{\circ}$ (c $\left.\left.0.4, \mathrm{CHCl}_{3}\right)\right]^{7} ;{ }^{1} \mathrm{H} \mathrm{NMR}$ and ${ }^{13} \mathrm{C} \mathrm{NMR}$ data were consistent with those previously reported ${ }^{7} \mathrm{ESI}-\mathrm{MS}, \mathrm{m} / \mathrm{z}$ $305[\mathrm{M}+\mathrm{H}]^{+}$.

\section{(-)-Eperuic acid (5)}

Colorless oil; $[\alpha]_{\mathrm{D}}^{25}-29.9^{\circ}\left(c 1.0, \mathrm{CHCl}_{3}\right) ;{ }^{1} \mathrm{H} \mathrm{NMR}(500$ $\left.\mathrm{MHz}, \mathrm{CDCl}_{3}\right) \delta 4.73(1 \mathrm{H}, \mathrm{d}, J 1.5 \mathrm{~Hz}, \mathrm{H}-17), 4.40(1 \mathrm{H}$, d, $J 1.5 \mathrm{~Hz}, \mathrm{H}-17), 2.30$ (1H, dd, $J 15.0,5.5 \mathrm{~Hz}, \mathrm{H}-14)$, 2.30 (1H, ddd, J 13.1, 4.0, 2.0 Hz, H-7), 2.04 (1H, dd, J 15.0, $8.5 \mathrm{~Hz}, \mathrm{H}-14), 1.89$ (1H, ddd, $J 13.1,12.5,5.2 \mathrm{~Hz}$, H-7), 1.70 (2H, m, H-1, H-11 or H-12), 1.65 (1H, dddd, $J$ 12.5, 5.2, 2.5, 2.0 Hz, H-6), 1.46 (3H, m, H-2, H-9, H-11 or H-12), 1.41 (1H, m, H-2), 1.32 (1H, br, dt, $J 12.5,3.5$ Hz, H-3), 1.24 (1H, qd, J 12.5, 4.0 Hz, H-6), 1.20 (2H, m, H-11, H-12), 1.11 (1H, td, J 12.5, 3.0 Hz, H-3), 1.02 (1H, dd, $J 12.5,2.5 \mathrm{~Hz}, \mathrm{H}-5), 1.02$ (1H, m, H-13), 0.95 (1H, td, $J$ 13.0, $4.0 \mathrm{~Hz}, \mathrm{H}-1), 0.90$ (3H, d, J $6.5 \mathrm{~Hz}, \mathrm{H}-16), 0.80$ (3H, s, H-18), 0.73 (3H, s, H-19), 0.60 (3H, s, H-20); ${ }^{13} \mathrm{C}$ NMR (126 MHz, $\left.\mathrm{CDCl}_{3}\right) \delta 178.9$ (C-15), 148.7 (C-8), 106.3 (C-17), 57.2 (C-9), 55.6 (C-5), 42.2 (C-3), 41.2 (C14), 39.7 (C-10), 39.1 (C-1), 38.4 (C-7), 35.9 (C-12), 33.6 (C-4, C-18), 30.9 (C-13), 24.4 (C-6), 21.7 (C-19), 20.9 (C-11), 19.9 (C-16), 19.4 (C-2), 14.4 (C-20); ESI-MS, $m / z 307[\mathrm{M}+\mathrm{H}]^{+}$.

\section{(-)-Kolavenic acid (6)}

Colorless crystals: mp 97-98 ${ }^{\circ} \mathrm{C}$; $[\alpha]_{\mathrm{D}}^{25}-42.0^{\circ}$ (c 1.0, $\mathrm{CHCl}_{3}$ ) [lit. $\left.-41.4^{\circ}\left(c 1.0, \mathrm{CHCl}_{3}\right)\right]^{7}$; IR, ${ }^{1} \mathrm{H} \mathrm{NMR}$, and ${ }^{13} \mathrm{C}$ NMR data were consistent with those previously reported ${ }^{7}$ ESI-MS, $m / z, 305[\mathrm{M}+\mathrm{H}]^{+}$.

\section{(-)-Hinokinin (7)}

Yellow oil: $[\alpha]_{\mathrm{D}}^{25}-31.5^{\circ}\left(c\right.$ 1.0, $\left.\mathrm{CHCl}_{3}\right)\left[\right.$ lit. $-30.3^{\circ}(c$ $\left.\left.0.6, \mathrm{CHCl}_{3}\right)\right]^{7} ; \mathrm{IR}, \mathrm{UV},{ }^{1} \mathrm{H} \mathrm{NMR}$, and ${ }^{13} \mathrm{C}$ NMR data were consistent with those previously reported ${ }^{7}$ ESI-MS, $\mathrm{m} / \mathrm{z}$ $355[\mathrm{M}+\mathrm{H}]^{+}$. 


\section{(-)-Kusunokinin (8)}

Yellow oil: $[\alpha]_{\mathrm{D}}^{25}-42.0^{\circ}\left(c\right.$ 1.1, $\left.\mathrm{CHCl}_{3}\right)$ [lit. $-40.0^{\circ}(c$ $\left.\left.0.2, \mathrm{CHCl}_{3}\right)\right]^{7}$; IR, UV, ${ }^{1} \mathrm{H}$ NMR, and ${ }^{13} \mathrm{C}$ NMR data were consistent with those previously reported; ${ }^{7}$ ESI-MS, $\mathrm{m} / \mathrm{z}$ $371[\mathrm{M}+\mathrm{H}]^{+}$.

(-)- $\left(8 R, 8^{\prime} R, 9 R\right)-$ Cubebin $+(-)-\left(8 R, 8^{\prime} R, 9 S\right)$-cubebin (9)

Colorless crystals: mp $126-128{ }^{\circ} \mathrm{C}$ [lit. $\left.127-128{ }^{\circ} \mathrm{C}\right]^{7}$; $[\alpha]_{\mathrm{D}}^{25}-42.5^{\circ}\left(c \quad 1.0, \mathrm{CHCl}_{3}\right)\left[\text { lit. }-41.5^{\circ}\left(c \quad 0.4, \mathrm{CHCl}_{3}\right)\right]^{7}$; ${ }^{1} \mathrm{H}$ NMR and ${ }^{13} \mathrm{C}$ NMR data were consistent with those previously reported; ${ }^{8}$ ESI-MS, $m / z, 357[\mathrm{M}+\mathrm{H}]^{+}$.

\section{$\beta$-Sitosterol (10)}

Colorless crystals: mp $138-140{ }^{\circ} \mathrm{C}$ [lit. $\left.137-139{ }^{\circ} \mathrm{C}\right]^{13}$; ${ }^{1} \mathrm{H}$ and ${ }^{13} \mathrm{C}$ NMR data were consistent with those previously reported; ${ }^{13}$ ESI-MS, $m / z 415[\mathrm{M}+\mathrm{H}]^{+}$.

\section{Sequoyitol (11)}

Colorless crystals: mp $238-240{ }^{\circ} \mathrm{C}$ [lit. $\left.232-234{ }^{\circ} \mathrm{C}\right]^{14}$; ${ }^{1} \mathrm{H}$ NMR (500 MHz, DMSO- $\left.d_{6}\right) \delta 3.70(1 \mathrm{H}, \mathrm{t}, J 2.5 \mathrm{~Hz}$, $\mathrm{H}-4), 3.43(2 \mathrm{H}, \mathrm{t}, J 9.5 \mathrm{~Hz}, \mathrm{H}-2, \mathrm{H}-6), 3.46\left(3 \mathrm{H}, \mathrm{s}, \mathrm{OCH}_{3}\right.$ ), $3.14(2 \mathrm{H}, \mathrm{dd}, J 9.5,2.5 \mathrm{~Hz}, \mathrm{H}-3, \mathrm{H}-5), 2.69(1 \mathrm{H}, \mathrm{t}, J 9.5 \mathrm{~Hz}$, $\mathrm{H}-1) .{ }^{13} \mathrm{C}$ NMR data were consistent with those previously reported; ${ }^{14}$ ESI-MS, $m / z, 195[\mathrm{M}+\mathrm{H}]^{+}$.

\section{Trigonelline (12)}

Yellow solid: mp $216-219^{\circ} \mathrm{C}$ [lit. $218{ }^{\circ} \mathrm{C}$ dec. $]^{15} ;{ }^{1} \mathrm{H}$ NMR $\left(500 \mathrm{MHz}, \mathrm{DMSO}-d_{6}\right) \delta 9.20(1 \mathrm{H}, \mathrm{s}, \mathrm{H}-2), 8.88(1 \mathrm{H}$, d, J $5.5 \mathrm{~Hz}, \mathrm{H}-6), 8.76(1 \mathrm{H}, \mathrm{d}, J 8.0 \mathrm{~Hz}, \mathrm{H}-4), 8.02(1 \mathrm{H}, \mathrm{dd}$, $J$ 8.0, $5.5 \mathrm{~Hz}, \mathrm{H}-5), 4.36\left(3 \mathrm{H}, \mathrm{s}, \mathrm{N}-\mathrm{CH}_{3}\right) ;{ }^{13} \mathrm{C} \mathrm{NMR}(126$ MHz, DMSO- $\left.d_{6}\right) \delta 162.3$ (C-7), 145.9 (C-2), 144.7 (C-6), 144.0 (C-4), 139.8 (C-3), 126.7 (C-5), $47.6\left(\mathrm{~N}-\mathrm{CH}_{3}\right)$; ESI$\mathrm{MS}, m / z 138[\mathrm{M}+\mathrm{H}]^{+}$.

\section{Uracil (13)}

Yellow solid, mp $>300{ }^{\circ} \mathrm{C}$ [lit. $\left.335{ }^{\circ} \mathrm{C}\right]{ }^{15} ;{ }^{1} \mathrm{H}$ and ${ }^{13} \mathrm{C}$ NMR data were consistent with those previously reported; ${ }^{16}$ ESI-MS, $m / z 113[\mathrm{M}+\mathrm{H}]^{+}$.

\section{Essential oils}

Stems $(30 \mathrm{~g})$ were cut into small pieces and stored at $-8{ }^{\circ} \mathrm{C}$ until oil extraction. The essential oils were obtained by hydrodistillation in $250 \mathrm{~mL} \mathrm{H}_{2} \mathrm{O}$ for $4 \mathrm{~h}$, with simultaneous extraction of the distillate with GC-grade $n$-hexane $(1 \mathrm{~mL})$, which enabled separation of the essential oil in an ice-cooled oil receiver, in a modified Clevenger apparatus to reduce hydrodistillation over-heating artifacts. The oils were collected with the addition of GC-grade $n$-hexane $(1 \mathrm{~mL})$ and dried over anhydrous $\mathrm{Na}_{2} \mathrm{SO}_{4}$. The solutions were then dried over a molecular sieve and analysed by GC-MS. The composition of the volatile constituents was established by GC-MS analyses. Retention indices for all compounds were determined according to the equation proposed by Van den Dool and Kratz, ${ }^{17}$ using $n$-alkanes as standards. Adjusted retention times for each peak were determined by subtracting the retention time of methane from the retention time of each peak. Components were identified based on comparison of their mass spectra with those at the Mass Spectrometry Data Centre, ${ }^{18}$ Wiley and NBS Libraries ${ }^{19}$ and those described by Adams, ${ }^{20}$ as well as by comparison of their retention indices with data in the literature. ${ }^{9}$ In several cases, the essential oils were coinjected with compounds that had been previously isolated from Aristolochia species or purchased standard compounds.

\section{Standard compounds}

Aldrich kits containing: 24 standard hydrocarbons/ C5-C30, straight-chain alkanes (Aldrich 29,850-6); 19 fatty acids/C6-C24, straight-chain (Aldrich 29,851-4); fatty acid methyl esters/C6-C24 straight-chain (Aldrich 29,851-4). Compounds isolated and identified by spectroscopic methods (mainly by MS, ${ }^{1} \mathrm{H}$ and ${ }^{13} \mathrm{C}$ NMR) from Aristolochia species: spathulenol, $\beta$-caryophyllene, caryophyllene oxide, trans-nerolidol, vanillin, kobusone, calarene, and 2-oxocalarene.

\section{Statistical analysis}

The agglomerative hierarchical cluster analysis (HCA) and principal component analysis (PCA) were used as statistical methods to suggest the structure of the set and to analyse the variables in relation to the characteristics being studied. To reduce the scattering effects and to compare samples, the chromatograms from obtained oils were normalized by reducing the area under each chromatogram to a value of $1 .{ }^{21}$ Overall, 68 characteristics (chemical compounds, of which 67 were identified and one was unknown) were analysed in 10 oils by HCA and PCA (Table 1 and Table S1-Supplementary Information). The chemical compositions were determined from the chromatographic profiles for 2 oils of the Brazilian cultivated species, and taken from data described in the literature for 2 oils from Paraguay, and 6 oils from Argentina. Plots defined by PC1 (score 1) and PC2 (score 2) for the 68 characteristics were obtained for chromatographic data using Pirouette ${ }^{\circledR}$ version 3.11.22 The results were obtained using an original data matrix X ( 68 by 10 ) with 68 variables, 10 samples, 3 optimal factors, 1st derivative. Variances of PC1 (32.6168) and PC2 (3.9711) accounted for $79.90 \%$ and $9.73 \%$, respectively, of the total PCA variance. 


\section{Results and Discussion}

In the oils from cultivated species (fresh material), 17 compounds from the stem and 14 from the leaf were identified (Tables 2 and 3). The data from oils were compared with those described in the literature ${ }^{10,11}$ for oils obtained from the stems and leaves of A. giberti, to obtain evidence that could contribute to the identification of species through significant interspecific variability. The variation in the chemical constitutions of the essential oils was examined by taking into account the part of the plant, the year that the plant was collected, and its provenance. Brazilian oils were characterized by the highest concentration of sesquiterpene hydrocarbons in oil from leaves $(84.7 \%)$ and also the highest concentration of monoterpene hydrocarbons in oil from stems (78.3\%). In this study, hierarchical cluster analysis (HCA) was used to search for sample provenance patterns and to create a classification scheme to differentiate plant parts or chemotypes. In this analysis, the data regarding the chemical composition of the oils described in the literature for A. giberti from Argentina (fresh material),${ }^{10}$ involving 36 compounds (one unknown), and Paraguay (dried material) ${ }_{1}^{11}$ involving 46 compounds, were compared to those obtained in this study (25 compounds) (for further information see Supplementary Data). Based on similarities in the chemical composition, a dendogram was obtained (Figure 2). According to this dendogram, the oils could be separated into three distinct groups or chemotypes. The first and second groups (I and II) consisted of data of the stem and leaf oils, respectively, obtained from both Brazil and Argentina, and the third group (III) consisted of oils from Paraguay (I, II, and III; similarity index 0.652). The first group was greatly characterized by monoterpenes ( $\alpha$ - and $\beta$-pinene, sabinene, camphene, tricyclene, and $\alpha$-thujene). Thus, similar chemical profiles were detected

Table 2. List of investigated oils with provenance, collection date, and abbreviation used

\begin{tabular}{lccc}
\hline Code & Part of plant & Locality & Date \\
\hline SA-1 & stems & Argentina & July, 1994 \\
SA-2 & stems & Argentina & July, 1996 \\
SA-3 & stems & Argentina & June, 1997 \\
SA-4 & stems & Argentina & July, 1999 \\
SB & stems & Brazil & February, 2004 \\
SP & stems & Paraguay & December, 2000 \\
LA-1 & leaves & Argentina & May, 1994 \\
LA-2 & leaves & Argentina & June, 1994 \\
LB & leaves & Brazil & February, 2004 \\
LP & leaves & Paraguay & December, 2000 \\
\hline
\end{tabular}

in stem samples collected in different years, which suggests a retention of unique chemical profiles in different populations from Argentina and Brazil.

Similarly, an analysis of the data regarding the chemical composition by PCA (Principal Component Analyses) of the oils was performed to obtain information about the characteristic compounds, which are the most discriminating for the samples observed in the plots (Figures 3 and 4). Except for stem oil from Paraguay (SP), they showed the highest positive scores of

Table 3. Composition of essential oils of stems and leaves from Brazilian A. giberti

\begin{tabular}{|c|c|c|c|}
\hline \multirow{2}{*}{$\mathrm{I}^{\mathrm{a}} / \mathrm{s}$} & \multirow{2}{*}{ Compound } & \multicolumn{2}{|c|}{ Species (code) } \\
\hline & & $\mathrm{SB}(\%)^{\mathrm{b}}$ & $\mathrm{LB}(\%)^{\mathrm{c}}$ \\
\hline 922 & $\alpha$-Thujene & 0.6 & - \\
\hline 934 & $\alpha$-Pinene & 2.9 & - \\
\hline 973 & $\beta$-Pinene & 0.7 & - \\
\hline 984 & $\beta$-Myrcene & 6.5 & - \\
\hline 1006 & $\delta$-3-Carene & 4.5 & - \\
\hline 1013 & $\alpha$-Phellandrene & 25.6 & - \\
\hline 1014 & $o$-Cymene & 20.4 & - \\
\hline 1023 & Limonene & 15.1 & - \\
\hline 1030 & cis-Ocimene & 2.0 & - \\
\hline 1184 & 4(10)-Thujen-3-ol & 1.2 & - \\
\hline 1391 & $\beta$-Elemene & - & 1.3 \\
\hline 1415 & $\beta$-Caryophyllene & 3.6 & 15.9 \\
\hline 1446 & $\alpha$-Aromadendrene & - & 1.8 \\
\hline 1474 & Acoradiene & - & 1.2 \\
\hline 1481 & Germacrene D & 2.5 & 14.3 \\
\hline 1483 & Isoledene & - & 3.2 \\
\hline 1485 & $\beta$-Selinene & - & 1.4 \\
\hline 1492 & Guaia-3,9-diene & - & 1.4 \\
\hline 1495 & Germacrene A & 3.5 & 35.7 \\
\hline 1507 & Valencene & - & 4.2 \\
\hline 1524 & $\delta$-Cadinene & 0.7 & 4.3 \\
\hline 1569 & Spathulenol & 5.3 & 11.7 \\
\hline 1575 & (-)- $\beta$-Caryophyllene oxide & 3.1 & 1.9 \\
\hline 1645 & $\alpha$-Cadinol & - & 1.9 \\
\hline \multirow[t]{7}{*}{1674} & Bulnesol & 1.9 & - \\
\hline & Total & 100.1 & 100.2 \\
\hline & Terpenoids & & \\
\hline & Monoterpene hydrocarbons & 78.3 & 0.0 \\
\hline & Oxygenated monoterpenes & 1.2 & 0.0 \\
\hline & Sesquiterpenes hydrocarbons & 10.3 & 84.7 \\
\hline & Oxygenated sesquiterpenes & 10.3 & 15.5 \\
\hline
\end{tabular}

${ }^{\mathrm{a}} \mathrm{I}$ : linear retention index; ${ }^{\mathrm{b} S B}$ : stems, species collected in Brazil; ${ }^{\mathrm{C}} \mathrm{LB}$ : leaves, species collected in Brazil. 


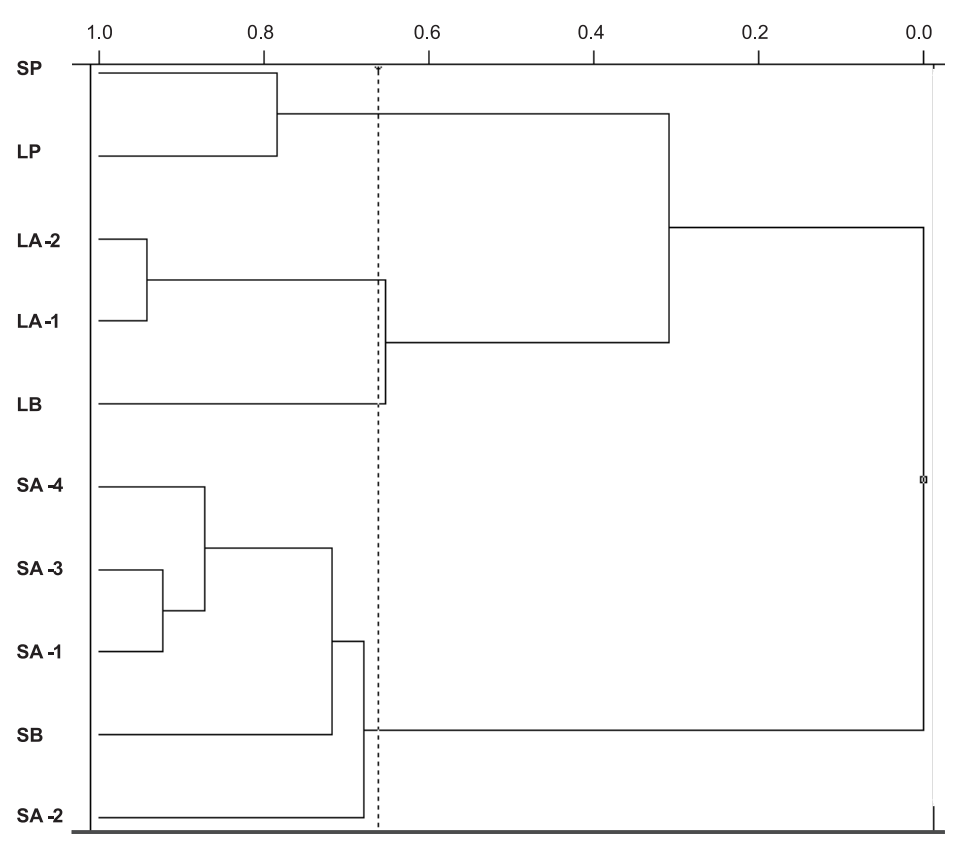

Figure 2. Dendogram constructed following agglomerative hierarchical clustering analysis (HCA) of essential oils of A. giberti of different provenances and collection dates.

principal component 1 (PC1) and similar PC2 (principal component 2) values for stem oils, which allowed us to differentiate them from the leaf oils (Figure 3). Oils characterized by the highest positive score signals for PC1 corresponded to stems that showed a predominance of monoterpenes, such as those included in group I by HCA as well as $\beta$-myrcene, $\delta$-3-carene, and $\alpha$-phellandrene (Figure 4), whereas the highest negative score signals showed a predominance of oxygenated monoterpenes, such as bornyl acetate and isobornyl formate. Leaf oils from Argentina (LA) and Brazil (LB) were characterized by positive scores of PC2 and by oxygenated sesquiterpenes, such as aristolactone and $\alpha$-cadinol. Oils from Paraguay (LP and SP) were characterized by negative loading of PC2 for sesquiterpenes, such as $\delta$-cadinene and germacrene B (Figure 4). These plots also showed the similarity between stem oils from Argentina and Brazil, which provided evidence regarding the identity of the species and that these oils show insignificant annual chemical variability. However, as shown by HCA, the oils from Paraguay were not well-discriminated by PCA analysis, suggesting that the best results for discriminating the part of the plant and its provenance can be achieved by using fresh material.

Phytochemical studies on hexane and ethanol extracts from A. giberti led to the isolation of a new tetracyclic triterpene [(-)-onocera-8, 8 '-diol (1)], five diterpenes

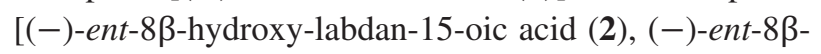
hydroxy-labd-13(E)-en-15-oic acid (3), (-)-copalic acid (4), (-)-eperuic acid (5), and (-)-kolavenic acid (6)], and three lignans [(-)-hinokinin (7), (-)-kusunokinin
(8), and (-)-cubebin (9)], as well as $\beta$-sitosterol (10), sequoyitol (11), trigonelline (12), and uracil (13). In addition, 3-hydroxypropanoate, acetate, and formate were detected by NMR techniques, which suggested that they are derived from a natural, yet undetectable compound of 2-butynedioate (14) (Figure 1).

Compounds 1, 2, 4-9, and 11-14 were isolated by partition and chromatographic procedures from the ethanol extracts of the leaves, whereas compounds $\mathbf{2}, \mathbf{3 , 6 - 8}$, and 10 were obtained by chromatographic procedures from the hexane extract of stems. A. giberti was a rich source of the diterpene (-)-ent-8 $\beta$-hydroxy-labdan-15-oic acid (2), which represents $8.0 \%$ of the ethanol and $21.9 \%$ of the ethanol Soxhlet extracts from the leaves.

The structures of compounds 4, 6-11, and $\mathbf{1 3}$ were identified by comparison of their spectroscopic data (ESI-MS, IR, 1D- and 2D- ${ }^{1} \mathrm{H}$ and ${ }^{13} \mathrm{C}$ NMR) and optical activities $\left(\alpha_{\mathrm{D}}\right)$ with those reported in the literature. ${ }^{7,13-16}$ Compounds $\mathbf{4}$ and 6-9 were also identified with reference to authentic samples obtained from Aristolochia malmeana. ${ }^{7}$ Compound 12 was identified as trigonelline by 1D- and 2D${ }^{1} \mathrm{H}$ and ${ }^{13} \mathrm{C}$ NMR and by comparison of its spectroscopic data with those reported for trigonellinium chloride and monohydrate. ${ }^{23}$ Although labdane derivatives from 2, 3, and $\mathbf{5}$ have been known for some time, and have even been isolated from Aristolochiaceae species, ${ }^{1,24,25}$ most of their spectroscopic data still remain to be described. A detailed analysis of ${ }^{1} \mathrm{H}-{ }^{1} \mathrm{H} g \mathrm{COSY}, g \mathrm{NOESY}, g \mathrm{HMQC}$, and $g \mathrm{HMBC}$ data of these diterpenes enabled us to assign the majority of their chemical shifts to carbons and hydrogens in the 


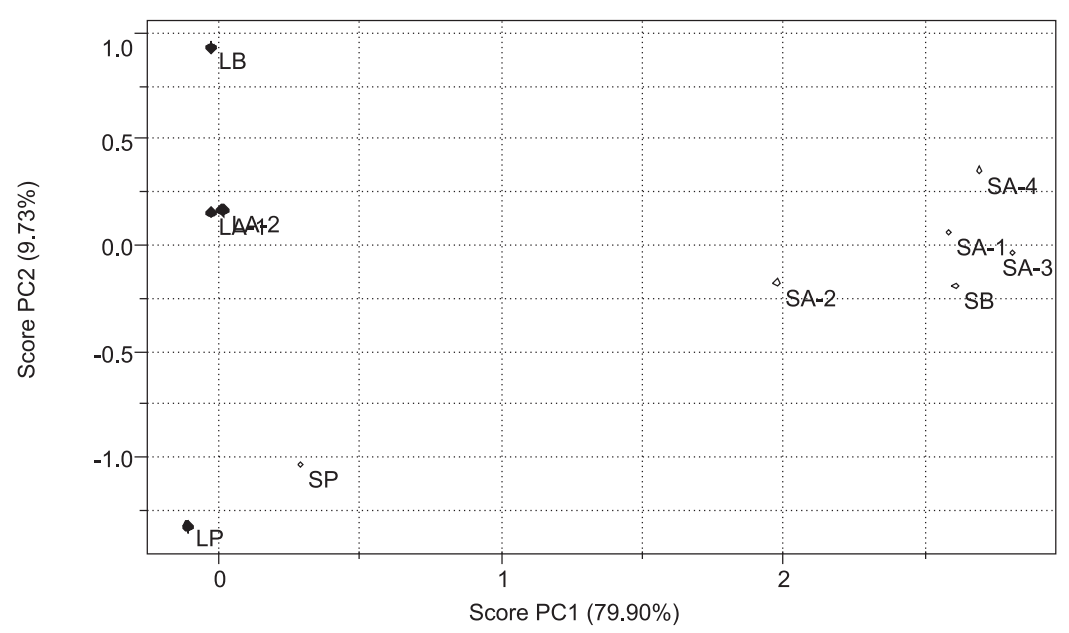

Figure 3. Principal component analysis (PCA) of chemical constituents of essential oils from stems and leaves of A. giberti. The principal components (PC1 and PC2) account for $c a .89 .6 \%$ of the information (for abbreviations of oils, see Table 2).

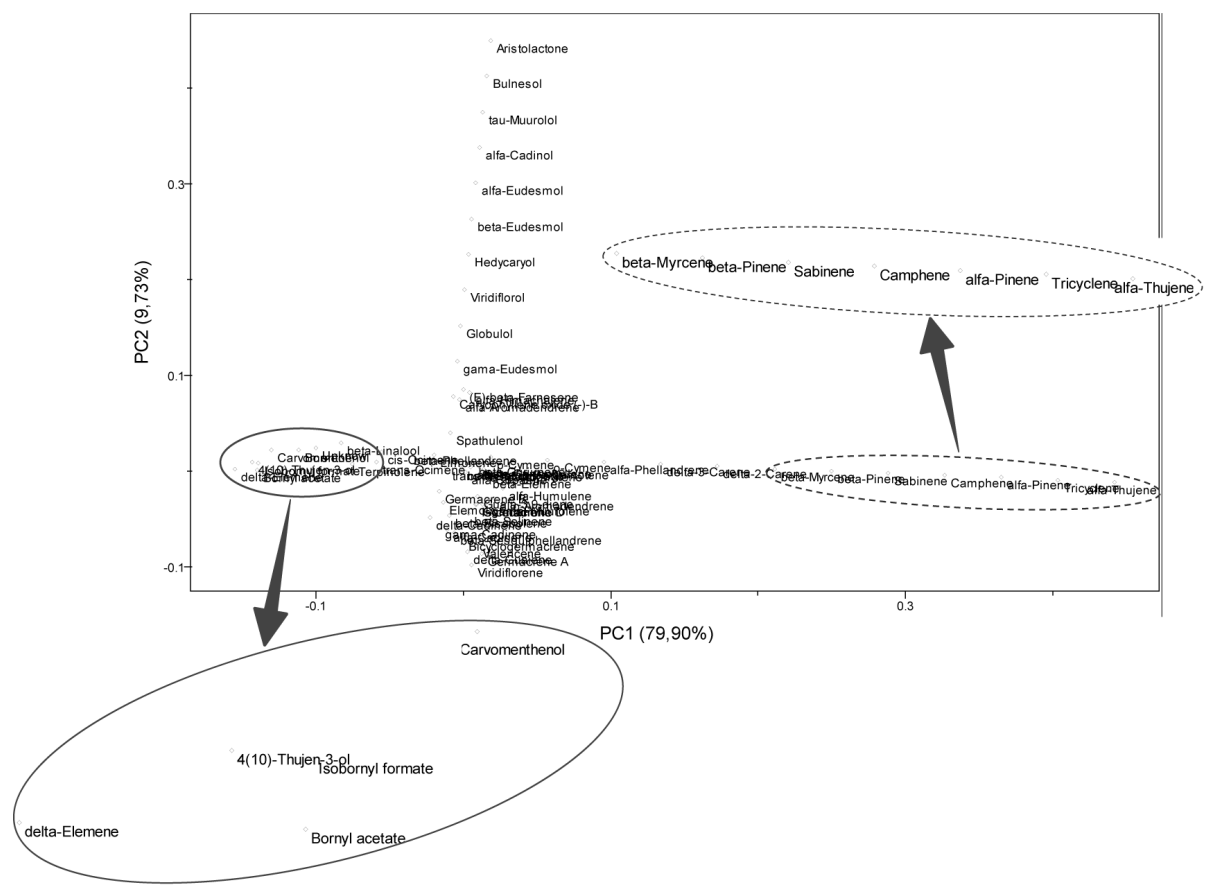

Figure 4. Loading plot of principal components (PC1 and $\mathrm{PC} 2)$ obtained for essential oils from the stems and leaves of A. giberti.

structures (Figure 5) and also helped to determine their relative configurations. Moreover, the coupling constants $(J)$ values determined for the hydrogens were confirmed by selective proton irradiation. The relative configuration established for 5 was corroborated by 1D gNOESY experiments that showed interactions between $\mathrm{CH}_{3}-20\left(\delta_{\mathrm{H}}\right.$ $0.60)$ and $\mathrm{H}-6\left(\delta_{\mathrm{H}} 1.24\right), \mathrm{H}-17 \mathrm{a}\left(\delta_{\mathrm{H}} 4.40\right)$, and $\mathrm{CH}_{3}-19\left(\delta_{\mathrm{H}}\right.$ $0.73)$, whereas $\mathrm{H}-17 \mathrm{~b}\left(\delta_{\mathrm{H}} 4.73\right)$ showed interaction with $\mathrm{H}-17 \mathrm{a}\left(\delta_{\mathrm{H}} 4.40\right), \mathrm{H}-7 \mathrm{a}\left(\delta_{\mathrm{H}} 2.30\right)$, and $\mathrm{H}-11 \mathrm{a}\left(\delta_{\mathrm{H}} 1.20\right)$. This latter also showed interaction with $\mathrm{C}_{3}-20\left(\delta_{\mathrm{H}} 0.60\right)$. Compounds $\mathbf{2}$ and $\mathbf{3}$ showed characteristic chemical shifts for $\mathrm{CH}_{3}-17\left(\delta_{\mathrm{C}} c a .30\right)$ in equatorial positions on the $\mathrm{B}$ rings. Consequently, $\mathrm{OH}-8$ must be in axial positions. In this case, hydrogens of $\mathrm{CH}_{3}-20$ were shifted downfield $\left(\Delta \delta_{\mathrm{H}}\right.$ $c a .+0.16)$ in relation to those for labdanes in normal series, which present an opposite relative configuration at C-8 (e.g. they show $\delta_{\mathrm{H}-20} c a .0 .78$ and $\mathrm{OH}-8$ in equatorial positions). ${ }^{26}$ This deduction was further confirmed by $1 \mathrm{D}$-gNOESY experiments for $\mathbf{2}$ and $\mathbf{3}$, which showed spatial interactions between $\underline{\mathrm{CH}}_{3}-19\left(\delta_{\mathrm{H}} c a .0 .82\right)$ and $\mathrm{C}_{3}-20\left(\delta_{\mathrm{H}} c a .0 .94\right)$, $\mathrm{C}_{3}-18\left(\delta_{\mathrm{H}} c a .0 .86\right)$, and H-3eq $\left(\delta_{\mathrm{H}} c a .1 .50\right)$, as well as between $\mathrm{CH}_{3}-17\left(\delta_{\mathrm{H}} c a .1 .11\right)$ and $\mathrm{H}-9\left(\delta_{\mathrm{H}} c a .0 .74\right)$, $2 \mathrm{H}-7\left(\delta_{\mathrm{H}} c a .1 .47,1.74\right)$, and $\mathrm{H}-11\left(\delta_{\mathrm{H}} c a .1 .33\right)$. Based on these data and the optical activities, compounds 2 and 3 were identified as (-)-ent-8 $\beta$-hydroxy-labdan-15-oic acid and (-)-ent-8$\beta$-hydroxy-labd-13(E)-en-15-oic acid, 
respectively. Both were previously isolated from Aristolochia galeata, ${ }^{25}$ and compound $\mathbf{5}$ was determined to be (-)-eperuic acid. Based on the identity of the observed optical activity of 5 with that reported for its methyl ester derivatives, ${ }^{26} \mathrm{a}$ 13(S) configuration could be established for 5; while the optical activity of $\mathbf{2}$ differed from that report for its 13(R) diastereomer methyl ester. ${ }^{27}$ Thus, diterpenes $\mathbf{2}$ and $\mathbf{5}$ should belong to ent labdane series and has a 13(S) configuration.
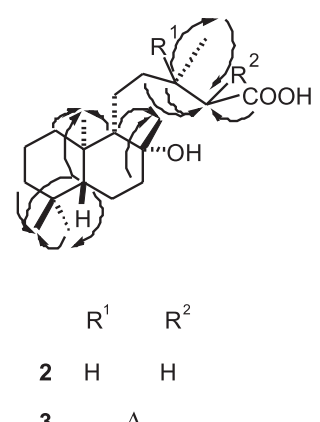

Figure 5. Selected $g \mathrm{HMBC}$ correlations $(\rightarrow$ ) for diterpenes $\mathbf{2 ,} \mathbf{3}$, and $\mathbf{5}$.

The ${ }^{1} \mathrm{H}$ NMR spectrum of compound $\mathbf{1}$ was similar to that of $\mathbf{2}$. The main difference between them was the absence of a doublet corresponding to $\mathrm{CH}_{3}-16$ in the spectrum of 1. The ${ }^{13} \mathrm{C}$ NMR and DEPT $\left(135^{\circ}\right.$ and $\left.90^{\circ}\right)$ spectra of $\mathbf{1}$ showed signals for 15 carbons, including four $\mathrm{CH}_{3}, \mathrm{six}_{2}$, two $\mathrm{CH}$, and three quaternary carbons. These data (Table 1), together with the great similarity between ${ }^{1} \mathrm{H}$ and ${ }^{13} \mathrm{C}$ NMR spectra of $\mathbf{1}$ and those of $\mathbf{2}$ (for further information see Experimental and Supplementary Information, Figures $\mathrm{S} 1$ and S2), as well as the $J$ values determined for the hydrogens by selective proton irradiation, suggested that, except for the substituents at C-9 (side chain), the A and B rings in the structures of both compounds were identical, including their relative configurations.

The HRMS spectra showed quasi-molecular ions $[\mathrm{M}+\mathrm{Na}]^{+}$at $m / z 469.4018$ for $\mathbf{1}$, which were consistent with the molecular formula $\mathrm{C}_{30} \mathrm{H}_{54} \mathrm{O}_{2}+\mathrm{Na}$. Based on the HRMS and NMR experiments, particularly on the presence of a $\mathrm{CH}_{2}\left(\delta_{\mathrm{C}} 20.1, \delta_{\mathrm{H}} 0.89\right)$, the structure of $\mathbf{1}$ was determined to be a triterpene, which consisted of two identical sesquiterpene units. Moreover, the correlations observed by $g \mathrm{HMBC}$ and $1 \mathrm{D} g$ NOESY experiments (irradiating at methyl hydrogen frequencies) allowed us to establish that the monomer units should be linked through C-11, C-11' (Figure 6). The chemical shifts of C-12,12' $\left(\delta_{\mathrm{C}} 30.7\right)$ and methyl groups $\mathrm{CH}_{3}-15,15^{\prime}\left(\delta_{\mathrm{H}} 0.88\right)$ are in accordance with equatorial $\mathrm{CH}_{3}-12,12$ ' on the $\mathrm{B}$ and $\mathrm{B}$ ' rings. Thus, as observed for $\mathbf{2}$ and $\mathbf{3}$, the hydroxyl groups at C-8, $8^{\prime}\left(\delta_{\mathrm{C}}\right.$ 73.3) should be in axial positions on the $\mathrm{B}$ and $\mathrm{B}$ ' rings, which was further supported by $1 \mathrm{D}-\mathrm{gNOESY}$ experiments (Figure 6).

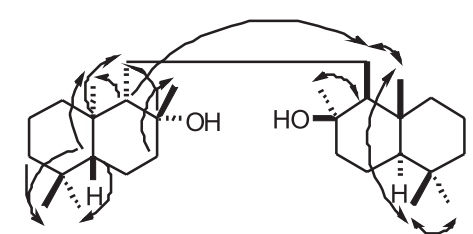

Figure 6. Selected $g \mathrm{HMBC}$ correlations $(\rightarrow)$ and nOe interactions $(\leftrightarrow)$ for triterpene $\mathbf{1}$.

Syntheses of onoceranols with diverse configurations have been described in the literature. ${ }^{29-31}$ Vlad et $a l .{ }^{29}$ synthesized $\left(5 S, 8 R, 9 R, 10 S, 5^{\prime} S, 8^{\prime} R, 9^{\prime} R, 10^{\prime} S\right)$ onoceranediol (1a) (Figure 7). However, the ${ }^{13} \mathrm{C}$ NMR data for C-8, $8^{\prime}\left(\delta_{\mathrm{C}} 74.6\right)$ and its neighbouring carbons, such as C-12,12' $\left(\delta_{\mathrm{C}} 24.4\right)$, differ from those of $\mathbf{1}$, which infers that these compounds have distinct relative configurations at C-8,8' (Figure 7). Corey and Sauers ${ }^{30}$ synthesized 1a and its correspondent epimer at C-8,8' (1) $)$, which showed $[\alpha]_{\mathrm{D}}+13^{\circ}$ and $+42^{\circ}$, respectively. Since compound $\mathbf{1}$ showed $[\alpha]_{D}-4.0^{\circ}$ and presents a symmetrical structure, as evidenced by its NMR spectra, its absolute configuration was determined to be $\left(5 R, 8 R, 9 S, 10 R, 5^{\prime} R, 8^{\prime} R, 9^{\prime} S, 10^{\prime} R\right)$. Hence, it should belong to the ent-series like the other diterpenes isolated from this species. Compound $\mathbf{1}$ was named (-)-onocera-8,8'-diol.
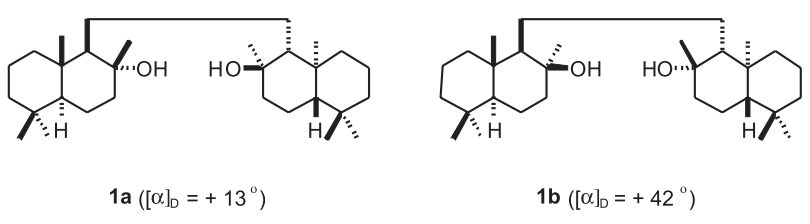

Figure 7. Structures for synthetic onocera-8,8'-diols $\mathbf{1 a}$ and $\mathbf{1 b}$.

A colorless amorphous solid (14) was isolated from the ethanol Soxhlet extract of leaves, and its ${ }^{1} \mathrm{H}$ NMR spectrum did not show any signals for hydrogen in $\mathrm{D}_{2} \mathrm{O}$, suggesting that, in principle, this solid was an inorganic compound. However, its undetermined melting point ( $c a$. $180^{\circ} \mathrm{C}$ ) showed its decomposition as well as its organic character. The ${ }^{1} \mathrm{H}$ and ${ }^{13} \mathrm{C}$ NMR spectra in DMSO- $d_{6}$, obtained on consecutive days from the soluble solution resulting from precipitation procedures, showed signals for hydrogens and carbons with diverse intensities, indicating the chemical transformation of compound 14. These spectra together with the results of DEPT, $g \mathrm{HMBC}$, and $g \mathrm{HMQC}$ experiments clearly indicated the formation of 3-hydroxypropanoate $\left(\mathbf{1 5}, \delta_{\mathrm{C}}\right.$ 177.3, 59.2, and 40.4, $\delta_{\mathrm{H}} 3.45$, and 2.08), acetate $\left(\mathbf{1 6}, \delta_{\mathrm{C}} 181.0\right.$, and 25.1, $\left.\delta_{\mathrm{H}} 1.63\right)$, and formate $\left(17, \delta_{\mathrm{C}} 167.7, \delta_{\mathrm{H}} 8.50\right)$. Similarly, the formation of these metabolites by in situ ${ }^{1} \mathrm{H}$ NMR analysis of two biotransformations of undetected 2-butynedioate and propynoate ('invisible substrates') was observed Brecker et al. ${ }^{32}$ using Pseudomonas putida. 
They determined the metabolic pathways of these two $\alpha$-alkynoates, in which the triple bonds in both 'invisible substrates' were initially hydrated, and 2-ketobutandioate as well as 3-ketopropanoate were then formed. These authors proposed that both $\beta$-keto acids were decarboxylated, resulting in pyruvate and acetaldehyde, respectively. Pyruvate was further hydrolyzed mainly to acetate and formate, whereas minor amounts were reduced to lactate. In the other biotransformation, acetaldehyde was oxidized to acetate accompanied by the reduction of 3-ketopropanoate to 3-hydroxypropanoate. ${ }^{32}$ Based on this finding, we propose that compound $\mathbf{1 4}$ was 2-butynedioate (not detected by ${ }^{~} \mathrm{H} \mathrm{NMR}$ ), which, via decarboxylation, could give rise to propynoate, which in turn could give 3-hydroxypropanoate and acetate, and hydration of compound $\mathbf{1 4}$ followed by decarboxylation, could lead to acetate and formate (Figure 8). Thus, the difference between this proposal and those regarding biotransformations is that $\mathbf{1 4}$ could give propynoate as one of the intermediates.

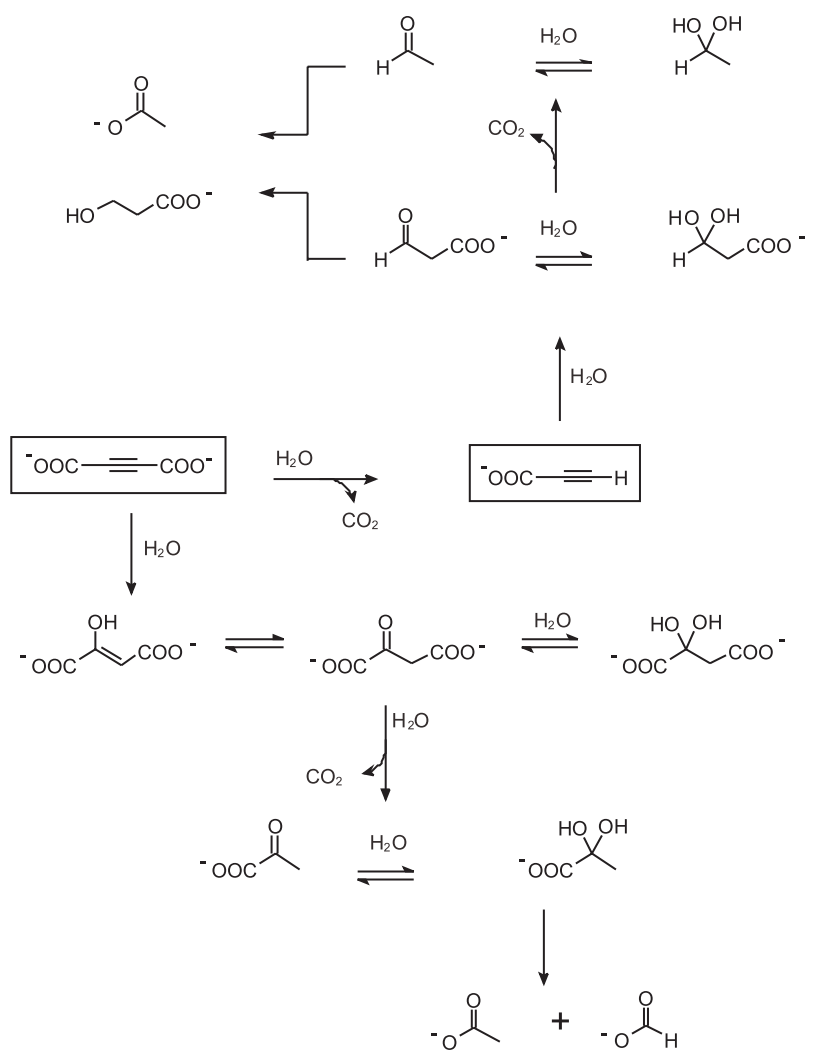

Figure 8. Proposed chemical pathways to 3-hydroxypropanoate, acetate, and formate from 2-butynedioate (14).

Sequoyitol (11), isolated from Aristolochia cymbifera and Aristolochia gigantea, among other species, ${ }^{1}$ has been shown to exhibit antidiabetic properties. ${ }^{33}$ Sequoyitol, (+)-pinitol, and aristolochic acids are oviposition stimulants for the pipevine swallowtail butterflies, Battus philenor and Atrophaneura alcinous (Papilionidae), which use Aristolochia species as major hosts. ${ }^{1}$ Trigonelline (12) is a natural zwitterion isolated from various plants, seeds and the western rock lobster. ${ }^{23}$ It has been shown to have hypoglycemic, hypolipidemic, hypocholesterolemic, insulinotropic, and antioxidant activities. ${ }^{34}$ These properties are related to the control of the Metabolic Syndrome, a disorder of carbohydrate and lipid metabolism which increases the risk of diabetes and cardiovascular disease. ${ }^{34}$ Therefore, trigonelline is a potential natural antidiabetic agent, as well as an antimicrobial and anti-dementia agent. ${ }^{35,36}$

\section{Conclusions}

A. giberti is a rich source of the diterpene and lignans. From this species, 14 compounds were isolated. Among them, a new triterperne, (-)-onocera-8,8'-diol (1), was isolated together with known compounds that are potential agents against several diseases such as diabetes. In addition, 3-hydroxypropanoate, acetate, and formate were also detected and were suggested to be derivatives from 2-butynedioate, which could not be detected by ${ }^{1} \mathrm{H}$ NMR. Moreover, a total of 25 compounds were identified in the essential oils from stems and leaves. GC-MS and chemometric analyses showed the great similarity between this cultivated species in Brazil and that collected in Argentina, and allowed us to confirm the species identity and to differentiate the oils according to the different parts of the plant.

\section{Acknowledgments}

The authors thank Condorcet Aranha and Lindolpho Capellari Jr. for plant identification. We also thank the Fundação de Amparo à Pesquisa do Estado de São Paulo (FAPESP) for financial support and fellowships to M. B. M., and the Conselho Nacional de Desenvolvimento Científico e Tecnológico (CNPq) for fellowships to A. M. M., G. G. P., and G. B. M.

\section{Supplementary Information}

Supplementary data for compound $\mathbf{1}$ are available free of charge at http://jbcs.sbq.org.br, as PDF file.

\section{References}

1. Lopes, L. M. X.; Nascimento, I. R.; da Silva, T. In Research Advances in Phytochemistry; Mohan, R. M. M., ed.; Global Research Network: Kerala, India, 2001, vol. 2, pp. 19-108.

2. Ioset, J.-R.; Raoelison, G. E.; Hostettmann, K.; Food Chem. Toxicol. 2003, 41, 29. 
3. Zang, C.-Y.; Wang, X.; Su, T.; Ma, C.-M.; Wen, Y.-J.; Shang, M.-Y.; Li, X.-M.; Liu, G.-X.; Cai, S.-Q.; Pharmazie 2005, 60, 785.

4. Andrade-Neto, V. F.; da Silva, T.; Lopes, L. M. X.; do Rosário, V. E.; Varotti, F. P.; Krettli, A. U.; Antimicrob. Agents Chemother. 2007, 51, 2346.

5. Oliveira, D. G.; Prince, K. A.; Higuchi, C. T.; Santos, A. C. B.; Lopes, L. M. X.; Simões, M. J. S.; Leite, C. Q. F.; J. Basic Appl. Pharm. Sci. 2007, 28, 165.

6. Nascimento, I. R.; Murata, A. T.; Bortoli, S. A. de; Lopes, L. M. X.; Pest Manage. Sci. 2004, 60, 413.

7. Messiano, G. B.;Vieira, L.; Machado, M. B.; Lopes, L. M. X.; Bortoli, S. A. de; Zukerman-Schpector, J.; J. Agric. Food Chem. 2008, 56, 2655.

8. Pascoli, I. C.; Nascimento, I. R.; Lopes, L. M. X.; Phytochemistry 2006, 67, 735.

9. Francisco, C. S.; Messiano, G. B.; Lopes, L. M. X.; Tininis, A. G.; Oliveira, J. E.; Capellari, L., Jr.; Phytochemistry 2008, 69, 168.

10. Priestap, H. A.; van Baren, C. M.; Lira, P. D. L.; Prado, H. J.; Neugebauer, M.; Mayer, R.; Bandoni, A. L.; Flavour Fragr. J. 2002, 17, 69.

11. Canela, N.; Ferro, E.; Alvarenga, N.; Vila, R.; Cañigueral, S.; J. Essent. Oil Res. 2004, 16, 566.

12. Velázquez, E.; Tournier, H. A.; Buschiazzo, P. M. de; Saavedra, G.; Schinella, G. R.; Fitoterapia 2003, 74, 91.

13. Nes, W. D.; Norton, R. A.; Benson, M.; Phytochemistry 1992, 31,805 .

14. Sultana, N.; Hartley T. G.; Waterman, P. G.; Phytochemistry 1999, 50, 1249.

15. Dictionary of Natural Products; The Chapman \& Hall/CRC Chemical Database, 2008; available at http://dpn.chemnetbase. com, accessed in November 2008.

16. Pouchert, C.; Behnke, J.; The Aldrich ${ }^{\circledR}$ Library of ${ }^{13} \mathrm{C}$ and ${ }^{1} \mathrm{H}$ FT-NMR Spectra, Aldrich Chemical: Milwaukee, WI, 1992, vol. 3, 365A.

17. Van den Dool, H.; Kratz, P. D.; J. Chromatogr. II, 1963, 463.

18. Houss, T. G.; Road, M.; Eight Peak Index of Mass Spectra, $4^{\text {th }}$ ed.; The Royal Society of Chemistry; The Mass Spectrometry Data Centre: Cambridge, UK, 1991, vols. 1-3.
19. Massada, Y.; Analysis of Essential Oil by Gas Chromatography and Spectrometry, John Wiley \& Sons: New York, NY, 1976.

20. Adams, R. P.; Identification of Essential Oil Components by Gas Chromatography/Mass Spectroscopy, $4^{\text {th }}$ ed.; Allured Publishing corporation: Carol Stream, IL, 2007.

21. Bertrand, D.; Scotter, S. N. G.; Appl. Spectrosc. 1992, 46, 1420.

22. Infometrix Inc. Pirouette ${ }^{\circledR}$ for Windows, version 3.11, Woodinville, WA, USA, 2003.

23. Szafran, M.; Koput, J.; Dega-Szafran, Z.; Katrusiak, A.; Pankowski, M.; Stobiecka, K.; Chem. Phys. 2003, 289, 201.

24. Nogueira, R. T.; Giacomini, R. A.; Shepherd, G. J.; Imamura, P. M.; J. Braz. Chem. Soc. 2002, 13, 389.

25. Lopes, L. M. X.; Bolzani, V. da S.; Phytochemistry 1988, 27, 2265.

26. Calderón, J. S.; Quijano, L.; Garduño, M.; Gómez, F.; Rios, T.; Phytochemistry 1983, 22, 2617.

27. Hugel, G.; Oehlschlager, A. C.; Ourisson, G.; Tetrahedron 1966, 22, 203.

28. Castro, J. M.; Salito, S.; Altarejos, J.; Nogueras, M.; Sánchez, A.; Tetrahedron 2002, 58, 5941.

29. Vlad, P. F.; Kuchkova, K. I.; Aryku, A. N.; Deleanu, K.; Russ. Chem. Bull., Int. Ed. 2005, 54, 2656.

30. Corey, E. J.; Sauers, R. R.; J. Am. Chem. Soc. 1959, 81, 1739.

31. Carman, R. M.; Deeth, H. C.; Aust. J. Chem. 1971, 24, 1099.

32. Brecker, L.; Petschnigg, J.; Depiné, N.; Weber, H.; Ribbons, D. W.; Eur. J. Biochem. 2003, 270, 1393.

33. Sun, T.; Wang, Y.; Wang, Y.; Lu, Y.; Wang, T.; Faming Zhuanli Shenqing Gongkai Shuomingshu 2008, 21pp.

34. Ibarra, A.; He, K.; Bai, N.; Bily, A.; Roller, M.; Coussaert, A.; Provost, N.; Ripoll, C.; Nat. Prod. Commun. 2008, 3, 1509.

35. Almeida, A. A. P.; Farah, A.; Silva, D. A. M.; Nunan, E. A.; Gloria, M. B. A.; J. Agric. Food Chem. 2006, 54, 8738.

36. Tohda, C.; Komatsu, K.; Nakamura, N.; Hattori, M.; Shokuhin Kogyo 2001, 44, 27.

Received: January 15, 2009

Web Release Date: August 31, 2009

FAPESP helped in meeting the publication costs of this article. 


\section{Chemical Constituents of Aristolochia giberti}

\section{Alessandra M. Marchesini, Giovana G. Prado, Gisele B. Messiano, Marcos B. Machado and Lucia M. X. Lopes*}

Instituto de Química, Universidade Estadual Paulista, CP 355, 14801-970 Araraquara-SP, Brazil

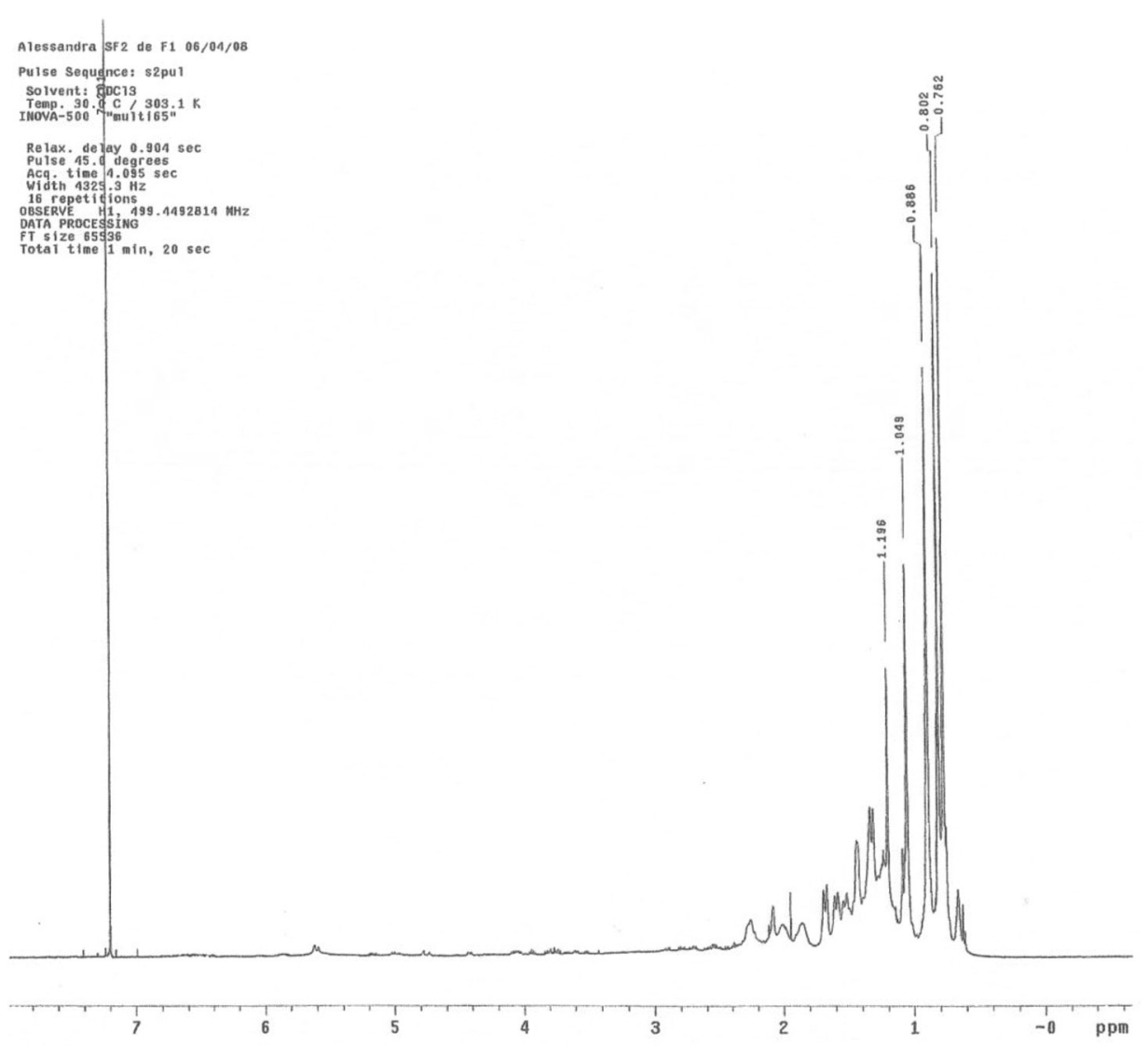

Figure S1. ${ }^{1} \mathrm{H}$ NMR spectrum of $\mathbf{1}\left(\mathrm{CDCl}_{3}, 500 \mathrm{MHz}, \delta\right)$. 

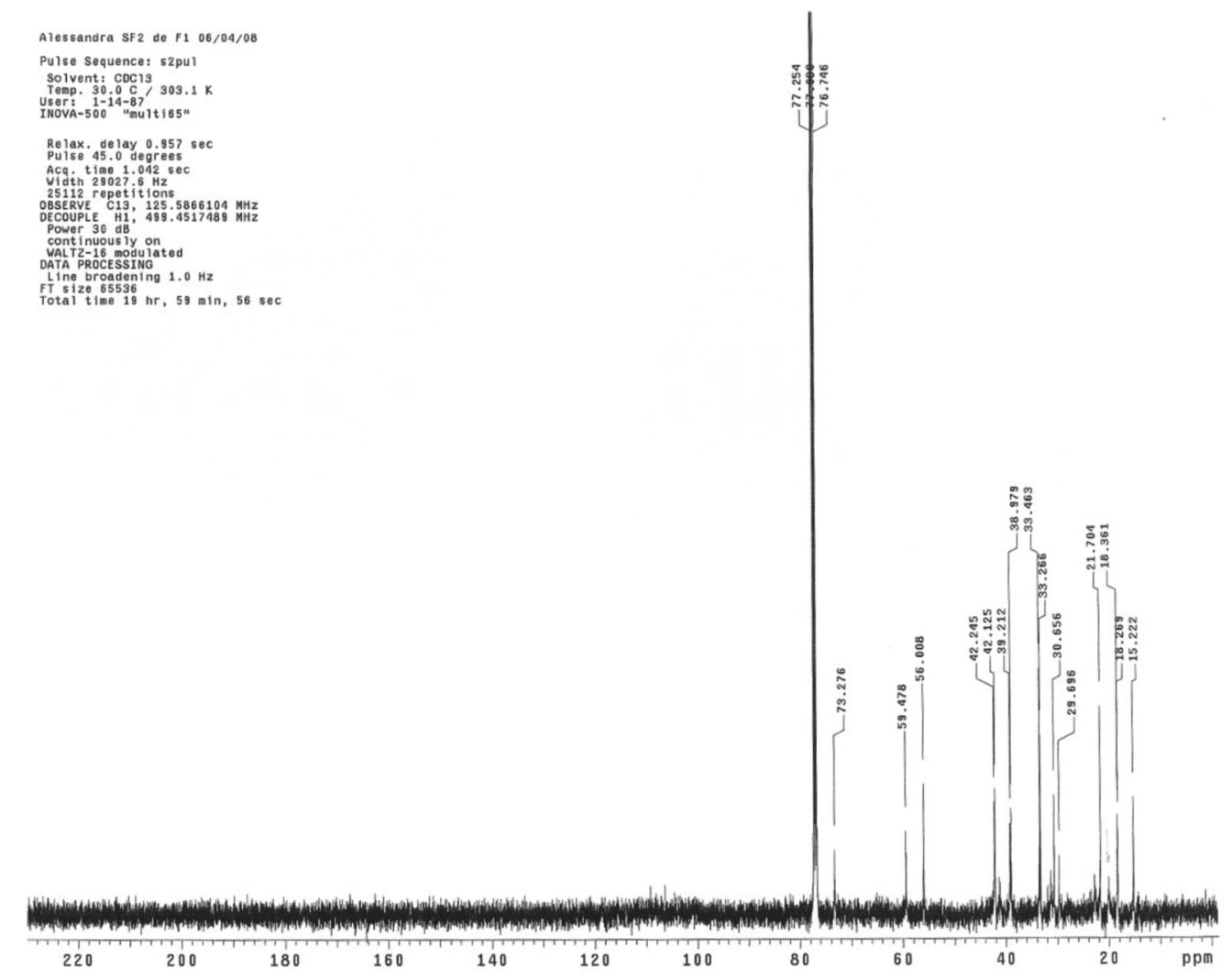

Figure S2. ${ }^{13} \mathrm{C}$ NMR spectrum of $\mathbf{1}\left(\mathrm{CDCl}_{3}, 126 \mathrm{MHz}, \delta\right)$.

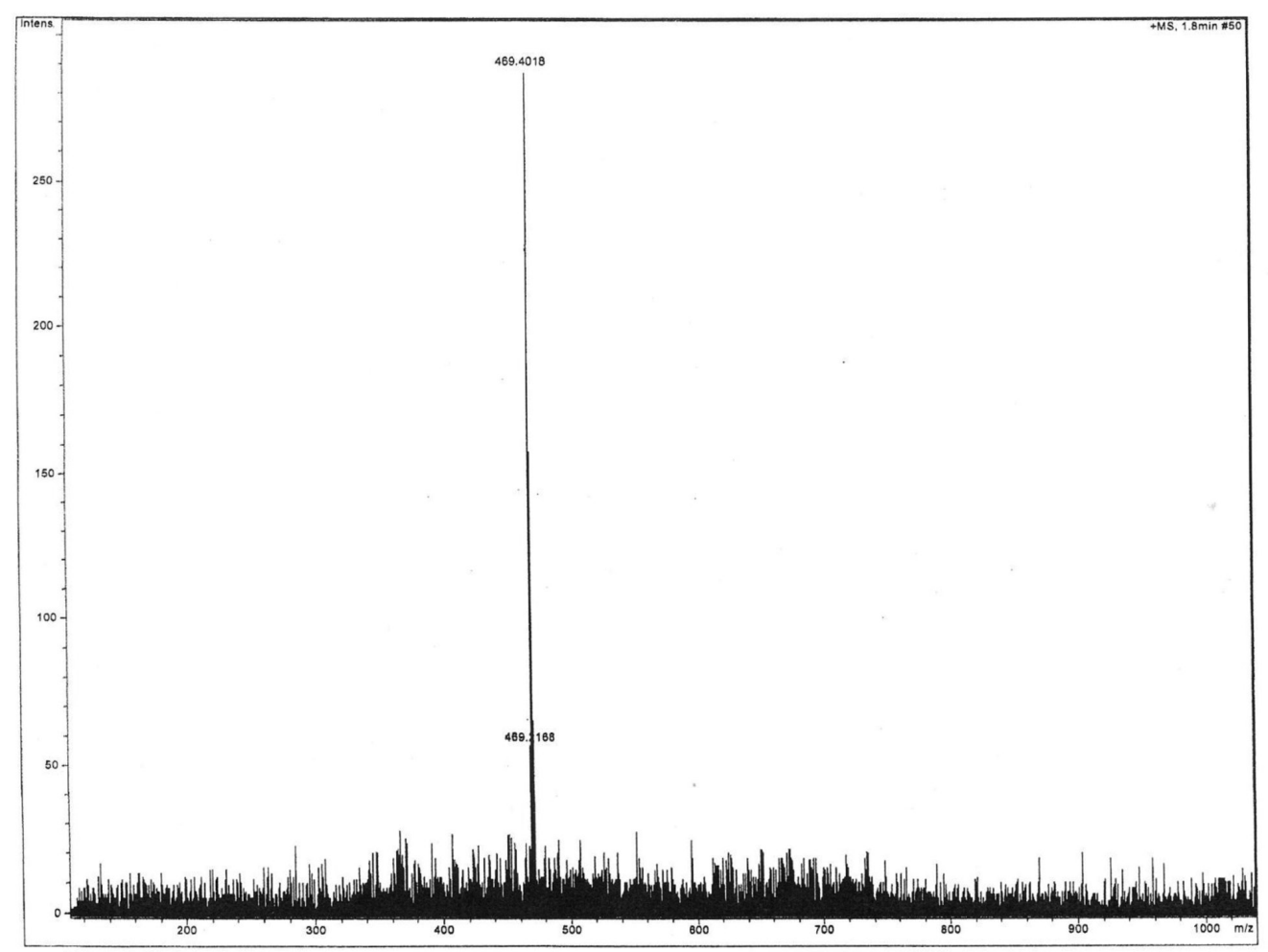

Figure S3. ESI-HR-TOF-MS spectrum of $\mathbf{1}$. 
Table S1. Chemical composition of essential oils of A. giberti from Brazil, Argentina, and Paraguay

\begin{tabular}{|c|c|c|c|c|c|c|c|c|c|c|c|c|}
\hline \multirow[b]{2}{*}{ Variable } & \multirow[b]{2}{*}{$\mathrm{I}^{\mathrm{a}} / \mathrm{s}$} & \multirow[b]{2}{*}{ Compound } & \multirow[b]{2}{*}{$\begin{array}{l}\mathrm{SB} / \\
(\%)\end{array}$} & \multirow[b]{2}{*}{$\begin{array}{l}\mathrm{LB} / \\
(\%)\end{array}$} & \multirow[b]{2}{*}{$\begin{array}{c}\text { LA-1/ } \\
(\%)\end{array}$} & \multirow[b]{2}{*}{$\begin{array}{c}\text { LA-2/ } \\
(\%)\end{array}$} & \multicolumn{2}{|c|}{ Species $(\text { code })^{\mathrm{b}-\mathrm{d}}$} & \multirow[b]{2}{*}{$\begin{array}{c}\text { SA-3 } \\
(\%)\end{array}$} & \multirow[b]{2}{*}{$\begin{array}{c}\text { SA-4 } \\
(\%)\end{array}$} & \multirow[b]{2}{*}{$\begin{array}{l}\mathrm{LP} \\
(\%)\end{array}$} & \multirow[b]{2}{*}{$\begin{array}{l}\text { SP } \\
(\%)\end{array}$} \\
\hline & & & & & & & $\begin{array}{c}\text { SA-1/ } \\
(\%)\end{array}$ & $\begin{array}{c}\text { SA-2/ } \\
(\%)\end{array}$ & & & & \\
\hline 1 & 922 & $\alpha$-Thujene & 0.6 & - & - & - & - & - & - & - & - & 0.1 \\
\hline 2 & 927 & Tricyclene & - & - & - & - & 0.1 & - & 0.1 & - & - & - \\
\hline 3 & 934 & $\alpha$-Pinene & 2.9 & - & - & - & 3.3 & 1.9 & 2.9 & 2.9 & 0.2 & 5.2 \\
\hline 4 & 948 & Camphene & - & - & - & - & 0.7 & 0.6 & 0.7 & 0.8 & - & - \\
\hline 5 & 953 & Sabinene & - & - & - & - & 0.1 & - & - & - & - & 0.5 \\
\hline 6 & 973 & $\beta$-Pinene & 0.7 & - & - & - & 0.9 & 0.4 & 0.7 & 0.8 & - & 1.4 \\
\hline 7 & 984 & $\beta$-Myrcene & 6.5 & - & - & - & 0.1 & 0.9 & 1.3 & 1.2 & - & 0.9 \\
\hline 8 & 996 & $\delta$-2-Carene & - & - & - & - & 0.2 & - & 0.2 & - & - & - \\
\hline 9 & 1006 & $\delta$-3-Carene & 4.5 & - & - & - & 0.8 & 1.0 & 0.8 & 0.7 & - & 0.8 \\
\hline 10 & 1013 & $\alpha$-Phellandrene & 25.6 & - & - & - & - & - & - & - & - & - \\
\hline 11 & 1014 & $o$-Cymene & 20.4 & - & - & - & - & - & - & - & - & - \\
\hline 12 & 1023 & $p$-Cymene & - & - & - & - & - & 0.1 & - & - & - & - \\
\hline 13 & 1023 & Limonene & 15.1 & - & 0.4 & 1.2 & 53.3 & 38.5 & 56.8 & 54.3 & 0.4 & 11.1 \\
\hline 14 & $\mathrm{e}$ & $\beta$-Phellandrene & - & - & - & - & - & - & - & - & - & 0.1 \\
\hline 15 & 1030 & cis-Ocimene & 2.0 & - & - & - & - & 0.9 & - & - & - & - \\
\hline 16 & 1041 & trans-Ocimene & - & - & 0.1 & 0.2 & 0.7 & 1.3 & 0.8 & 0.5 & - & 0.8 \\
\hline 17 & 1082 & Terpinolene & - & - & - & - & - & - & - & - & - & 0.2 \\
\hline 18 & 1087 & $\beta$-Linalool & - & - & - & - & - & - & - & - & - & 1.1 \\
\hline 19 & 1136 & Unknow & - & - & - & - & 0.7 & 0.5 & 0.7 & 0.7 & - & - \\
\hline 20 & 1151 & Borneol & - & - & 0.1 & 0.1 & 0.4 & 0.1 & 0.1 & 0.3 & - & - \\
\hline 21 & 1170 & Carvomenthenol & - & - & - & - & - & - & - & - & - & 0.3 \\
\hline 22 & 1184 & 4(10)-Thujen-3-ol & 1.2 & - & - & - & - & - & - & - & - & - \\
\hline 23 & 1218 & Isobornyl formate & - & - & - & - & 0.5 & 0.6 & 0.9 & 0.7 & - & - \\
\hline 24 & 1290 & Bornyl acetate & - & - & - & - & 0.1 & 0.1 & - & - & - & - \\
\hline 25 & 1340 & $\delta$-Elemene & - & - & 1.0 & 1.1 & 0.4 & 0.3 & 0.2 & - & 1.0 & - \\
\hline 26 & 1380 & $\alpha$-Copaene & - & - & 0.4 & 0.3 & 0.3 & 0.8 & 0.2 & 0.3 & 0.4 & 0.4 \\
\hline 27 & 1387 & $\beta$-Bourbonene & - & - & 0.5 & 0.5 & 0.4 & 0.8 & 0.3 & 0.4 & 0.8 & 0.7 \\
\hline 28 & 1391 & $\beta$-Elemene & - & 1.3 & 2.5 & 2.7 & 1.7 & 2.8 & 1.8 & 1.5 & 2.1 & - \\
\hline 29 & 1407 & Isocaryophyllene & - & - & - & - & - & - & - & - & - & 3.0 \\
\hline 30 & 1415 & $\beta$-Caryophyllene & 3.6 & 15.9 & 2.3 & 2.2 & 2.4 & 3.7 & 3.0 & 2.7 & 3.4 & 2.9 \\
\hline 31 & 1440 & $\beta$-Gurjunene & - & - & - & - & - & - & - & - & 0.7 & 0.9 \\
\hline 32 & $\mathrm{e}$ & $\alpha$-trans-Bergamotene & - & - & - & - & - & - & - & - & 0.4 & - \\
\hline 33 & $\mathrm{e}$ & $\alpha$-Himachalene & - & - & - & - & - & - & - & - & 0.7 & 0.4 \\
\hline 34 & $\mathrm{e}$ & $(E)$ - $\beta$-Farnesene & - & - & - & - & - & - & - & - & 3.6 & 0.2 \\
\hline 35 & 1446 & $\alpha$-Aromadendrene & - & 1.8 & 5.7 & 4.5 & 0.8 & 1.7 & 0.7 & 0.4 & - & - \\
\hline 36 & 1455 & $\alpha$-Humulene & - & - & - & - & 0.2 & - & 0.2 & 0.2 & - & - \\
\hline 37 & 1460 & allo-Aromadendrene & - & - & 0.6 & - & 0.2 & 0.4 & 0.2 & 0.3 & - & 0.5 \\
\hline 38 & 1470 & $\gamma$-Muurolene & - & - & - & - & - & - & - & - & 1.0 & - \\
\hline 39 & 1474 & Acoradiene & - & 1.2 & - & - & - & - & - & - & - & - \\
\hline 40 & 1481 & Germacrene D & 2.5 & 14.3 & 6.0 & 5.8 & 4.1 & 9.5 & 4.0 & 5.1 & 8.5 & 7.3 \\
\hline 41 & 1483 & Isoledene & - & 3.2 & - & - & - & - & - & - & - & - \\
\hline 42 & 1485 & $\beta$-Selinene & - & 1.4 & - & - & - & - & - & - & - & - \\
\hline
\end{tabular}


Table S1. Chemical composition of essential oils of A. giberti from Brazil, Argentina, and Paraguay

\begin{tabular}{|c|c|c|c|c|c|c|c|c|c|c|c|c|}
\hline \multirow[b]{2}{*}{ Variable } & \multirow[b]{2}{*}{$\mathrm{I}^{\mathrm{a}} / \mathrm{s}$} & \multirow[b]{2}{*}{ Compound } & \multicolumn{10}{|c|}{ Species (code) $)^{b-d}$} \\
\hline & & & $\begin{array}{l}\text { SB/ } \\
(\%)\end{array}$ & $\begin{array}{l}\mathrm{LB} / \\
(\%)\end{array}$ & $\begin{array}{c}\text { LA-1/ } \\
(\%)\end{array}$ & $\begin{array}{c}\text { LA-2/ } \\
(\%)\end{array}$ & $\begin{array}{c}\text { SA-1/ } \\
(\%)\end{array}$ & $\begin{array}{c}\text { SA-2/ } \\
(\%)\end{array}$ & $\begin{array}{c}\text { SA-3 } \\
(\%)\end{array}$ & $\begin{array}{c}\text { SA-4 } \\
(\%)\end{array}$ & $\begin{array}{l}\mathrm{LP} \\
(\%)\end{array}$ & $\begin{array}{l}\text { SP } \\
(\%)\end{array}$ \\
\hline 43 & 1492 & Guaia-3,9-diene & - & 1.4 & - & - & - & - & - & - & - & - \\
\hline 44 & 1495 & Viridiflorene & - & - & - & - & - & - & - & - & 1.3 & - \\
\hline 45 & 1495 & Germacrene A & 3.5 & 35.7 & - & - & - & - & - & - & - & - \\
\hline 46 & 1507 & Valencene & - & 4.2 & - & - & - & - & - & - & - & - \\
\hline 47 & $\mathrm{e}$ & $\delta$-Guaiene & - & - & - & - & - & - & - & - & 1.3 & - \\
\hline 48 & 1518 & Bicyclogermacrene & - & - & 42.2 & 38.1 & 7.6 & 16.5 & 10.7 & 9.8 & 26.8 & 15.0 \\
\hline 49 & $\mathrm{e}$ & $\beta$-Sesquiphellandrene & - & - & - & - & - & - & - & - & 4.0 & - \\
\hline 50 & $\mathrm{e}$ & $\alpha$-Cadinene & - & - & - & - & - & - & - & - & - & 2.1 \\
\hline 51 & 1520 & $\gamma$-Cadinene & - & - & 0.9 & 0.8 & 0.9 & 1.7 & 0.8 & 0.8 & 0.5 & - \\
\hline 52 & 1524 & $\delta$-Cadinene & 0.7 & 4.3 & - & - & - & - & - & - & 1.5 & 1.4 \\
\hline 53 & $\mathrm{e}$ & $\beta$-Bisabolene & - & - & - & - & - & - & - & - & 0.2 & - \\
\hline 54 & 1541 & Elemol & - & - & - & - & - & - & - & - & - & 1.7 \\
\hline 55 & 1548 & Germacrene B & - & - & - & 0.1 & - & - & - & - & 0.4 & 0.8 \\
\hline 56 & 1556 & trans-Nerolidol & - & - & - & - & 0.2 & 0.2 & 0.2 & 0.3 & 17.5 & 7.1 \\
\hline 57 & 1569 & Spathulenol & 5.3 & 11.7 & 7.4 & 12.8 & 3.0 & 3.1 & 2.2 & 2.5 & 3.4 & 7.3 \\
\hline 58 & 1575 & (-)- $\beta$-Caryophyllene oxide & 3.1 & 1.9 & - & - & - & - & - & - & - & - \\
\hline 59 & $\mathrm{e}$ & $\gamma$-eudesmol & - & - & - & - & - & - & - & - & - & 0.7 \\
\hline 60 & 1579 & Globulol & - & - & - & - & - & - & - & - & 0.6 & - \\
\hline 61 & 1582 & Viridiflorol & - & - & - & - & - & - & - & - & - & 0.9 \\
\hline 62 & $\mathrm{e}$ & Hedycaryol & - & - & - & - & - & - & - & - & - & 2.1 \\
\hline 63 & 1625 & $\beta$-Eudesmol & - & - & - & - & - & - & - & - & - & 1.0 \\
\hline 64 & 1631 & $\alpha$-Eudesmol & - & - & - & - & - & - & - & - & - & 0.7 \\
\hline 65 & 1645 & $\alpha$-Cadinol & - & 1.9 & - & - & - & - & - & - & 0.5 & 0.4 \\
\hline 66 & 1660 & $\tau$-Muurolol & - & - & - & - & - & - & - & - & - & 0.5 \\
\hline 67 & 1674 & Bulnesol & 1.9 & - & - & - & - & - & - & - & - & - \\
\hline \multirow[t]{9}{*}{68} & 2068 & Aristolactone & - & - & 7.7 & 9.9 & 3.2 & 1.6 & 2.2 & 5.8 & - & - \\
\hline & & Total & 100.1 & 100.2 & 77.8 & 80.3 & 87.3 & 90.0 & 92.7 & 93.0 & 81.2 & 80.5 \\
\hline & \multicolumn{12}{|c|}{ Terpenoids } \\
\hline & & Monoterpene hydrocarbons & 78.3 & 0.0 & 0.5 & 1.4 & 60.2 & 45.6 & 64.3 & 61.2 & 0.6 & 21.1 \\
\hline & & Oxygenated monoterpenes & 1.2 & 0.0 & 0.1 & 0.1 & 1.0 & 0.8 & 1.0 & 1.0 & 0.0 & 1.4 \\
\hline & & Sesquiterpene hydrocarbons & 10.3 & 84.7 & 62.1 & 56.1 & 19.0 & 38.2 & 22.1 & 21.5 & 58.6 & 35.6 \\
\hline & & Oxygenated sesquiterpenes & 10.3 & 15.5 & 15.1 & 22.7 & 6.4 & 4.9 & 4.6 & 8.6 & 22.0 & 22.4 \\
\hline & \multicolumn{12}{|c|}{ Aromatics } \\
\hline & & Others/unknown & 0.0 & 0.0 & 0.0 & 0.0 & 0.7 & 0.5 & 0.7 & 0.7 & 0.0 & 0.0 \\
\hline
\end{tabular}

${ }^{\mathrm{a}} \mathrm{I}$ : Linear retention index; ${ }^{\mathrm{b}}$ For abbreviations of oils, see Table $2 ;{ }^{\mathrm{c}}$ Data from reference 10 ; ${ }^{\mathrm{d}}$ Data from reference $11 ;{ }^{\mathrm{e}} \mathrm{Data}$ not available. 